Article

\title{
Nutrients Leaching in Response to Long-Term Fertigation and Broadcast Nitrogen in Blueberry Production
}

\author{
Aimé J. Messiga ${ }^{1, *}$, Kathryn Dyck ${ }^{1}$, Kiera Ronda ${ }^{1}$, Kolden van Baar $^{1}$, Dennis Haak ${ }^{1}$, \\ Shaobing $\mathrm{Yu}^{1}$ and Martine Dorais ${ }^{2}$ \\ 1 Agassiz Research and Development Centre, Agriculture and Agri-Food Canada, 6947 Highway 7, P.O. \\ Box 1000, Agassiz, BC V0M 1A0, Canada; Kathryn.Dyck@mytwu.ca (K.D.); kiera.ronda11@hotmail.ca (K.R.); \\ koldenv@uvic.ca (K.v.B.); adhaak@shaw.ca (D.H.); shaobing.yu@canada.ca (S.Y.) \\ 2 Centre de Recherche et d'Innovation sur les Végétaux (CRIV), Département de Phytologie, Faculté des \\ Sciences de l'Agriculture et de l'Alimentation, Université Laval, Québec (Québec), G1V 0A6, Canada; \\ martine.dorais@fsaa.ulaval.ca \\ * Correspondence: aime.messiga@canada.ca
}

Received: 28 October 2020; Accepted: 7 November 2020; Published: 10 November 2020

\begin{abstract}
Nutrient leaching losses from horticultural production threaten the quality of groundwater and freshwater systems worldwide. The objectives of this study were to (a) assess the effects of annual applications of ammonium sulfate fertilizer through fertigation (FERT) and broadcast (BROAD) on nutrient leaching losses and (b) determine the links among chemical property changes in leachates and soil with berry yields after 9 and 11 years of blueberry production. The long-term blueberry site was established in 2008 using seven combinations of treatments including an unfertilized control (CONT) and three $\mathrm{N}$ fertilizer rates $(100 \%, 150 \%, 200 \%$ of recommended rates) using BROAD and FERT methods. Nutrients concentrations $\left(\mathrm{NO}_{3}{ }^{-}-\mathrm{N}, \mathrm{NH}_{4}{ }^{+}-\mathrm{N}\right.$ and $\left.\mathrm{SO}_{4}{ }^{2-}-\mathrm{S}\right)$ and chemical properties $(\mathrm{pH}$ and electrical conductivity (EC)) of leachate, sawdust and soil and berries were assessed. All FERT methods resulted in concentrations of $\mathrm{NO}_{3}{ }^{-}-\mathrm{N}$ in the leachates $>100 \mathrm{mg} \mathrm{L}^{-1}$ with a maximum of 200 $\mathrm{mg} \mathrm{L}^{-1}$ for FERT-200 during the growing season due to the easy transport of dissolved nutrients with the irrigation water. All BROAD methods resulted into concentrations of $\mathrm{NO}_{3}{ }^{-}-\mathrm{N}$ in the leachates $>10 \mathrm{mg} \mathrm{L}^{-1}$ with a maximum of $35 \mathrm{mg} \mathrm{L}^{-1}$ for BROAD-200 between April and July, as well as between November and April, indicating two periods of $\mathrm{NO}_{3}{ }^{-}-\mathrm{N}$ leaching losses. The pattern observed with BROAD indicates that irrigation water in the summer and heavy rainfall in the winter contribute to $\mathrm{NO}_{3}{ }^{-}-\mathrm{N}$ leaching losses. Concentrations of $\mathrm{NH}_{4}{ }^{+}-\mathrm{N}$ in the leachates $>1 \mathrm{mg} \mathrm{L}^{-1}$ were measured under FERT with a peak at $64.78 \mathrm{mg} \mathrm{L}^{-1}$ for FERT-200, during the period April to August, due to $\mathrm{NH}_{4}{ }^{+ \text {'s }}$ ability to quickly move through the sawdust layer with irrigation water. Principal component analysis linked berry yield decrease with ammonium sulfate applications above recommended rates (FERT and BROAD) and with changes in soil $\mathrm{pH}$ and EC. Our results demonstrated that excess fertilizer applications above recommended rates using FERT and BROAD can threaten the sustainability of blueberry production by enhancing nutrient leaching losses and reducing berry yield.
\end{abstract}

Keywords: ammonium; British Columbia; leachates; nitrates; sawdust mulch; sulfate

\section{Introduction}

Nutrient leaching losses from horticultural production threaten the quality of groundwater and freshwater systems worldwide [1]. One of the main drivers of nutrient leaching is the excessive use and improper management of fertilizers that provide nutrients in amounts larger than the crop needs. Horticultural production systems are high value-added crops and farmers apply excess fertilizers 
because the probability of economic return is high [2]. A study conducted in Chinese farmland showed that nitrogen $(\mathrm{N})$ application rates in orchards were often higher than (1) the recommended $\mathrm{N}$ application rate and (2) the economic optimum $\mathrm{N}$ application rates [3]. In a 3-year study involving 29 raspberry trials in farmer fields in the Lower Fraser Valley of British Columbia (BC), Canada, high soil nitrate $\left(\mathrm{NO}_{3}{ }^{-}-\mathrm{N}\right)$ contents were frequently measured at the end of the growing season even at the recommended $\mathrm{N}$ rate, which indicates excess $\mathrm{N}$ fertility [4]. Excessive fertilizer applications can lead to high concentrations of nutrients in the soil and the nutrients not taken up by plants are prone to leaching.

Nutrient leaching losses can affect groundwater and freshwater systems in various ways. High $\mathrm{NO}_{3}{ }^{-}-\mathrm{N}$ loads can trigger eutrophication of surface waters and result in algal blooms and loss of fish [5]. Methemoglobinemia in infants and some forms of stomach cancer in adults have been linked to high concentrations of $\mathrm{NO}_{3}{ }^{-}-\mathrm{N}$ in drinking water [6]. These concerns have led to policies requiring farmers to adopt improved $\mathrm{N}$ management practices in areas sensitive to $\mathrm{NO}_{3}{ }^{-}-\mathrm{N}$ leaching and the establishment of critical $\mathrm{NO}_{3}{ }^{-}-\mathrm{N}$ concentration limits for drinking water $[7,8]$. Studies have also shown that ammonium $\left(\mathrm{NH}_{4}{ }^{+}-\mathrm{N}\right)$ may leach in sandy soils [9]. High concentrations of total ammonia $\left(>1 \mathrm{mg} \mathrm{L}^{-1}\right)$ in freshwater environments can be toxic to aquatic and semiaquatic plant species [10]. Fish species, such as Oncorhynchus mykiss (rainbow trout), were found to be negatively affected at ammonia concentrations as low as $0.04 \mathrm{mg} \mathrm{L}^{-1}$ [11]. Sulfate $\left(\mathrm{SO}_{4}{ }^{2-}-\mathrm{S}\right)$ leaching in horticultural production generally occurs as a result of excessive use of ammonium sulfate fertilizers [12]. It accumulates in the soil as a salt, which increases electrical conductivity (EC) and acidity [13]. Concentrations of $\mathrm{SO}_{4}{ }^{2-}-\mathrm{S}$ in the soils also depend on the dynamics of soil organic matter, as well as precipitation and temperature patterns during winter and spring [14]. Results from lysimeters and river catchment studies showed that $\mathrm{SO}_{4}{ }^{2-}-\mathrm{S}$ leaching ranges from 1 to $60 \mathrm{~kg} \mathrm{ha}^{-1}$ $\mathrm{yr}^{-1}$ [15], but values as high as $100 \mathrm{~kg} \mathrm{ha}^{-1} \mathrm{yr}^{-1}$ have also been reported [16].

Blueberries (Vaccinum corymbosum) grow best in acidic soils with optimal pH between 4.0 and 5.5 [17]. They take up $\mathrm{N}$ preferentially as $\mathrm{NH}_{4}{ }^{+}$compared with $\mathrm{NO}_{3}{ }^{-}$, and therefore blueberry farmers in most of $\mathrm{BC}$ use ammonium sulfate as their main source of $\mathrm{N}$ [13]. As for most horticultural crops, blueberries are high-value crops and surveys have shown that blueberry farmers in BC generally apply ammonium sulfate fertilizers at rates greater than recommended $[13,18]$. Another explanation for the excess $\mathrm{N}$ input in these horticultural production systems is the use of sawdust mulch, a carbon-rich material, on the surface of raised beds to improve weed control and limit evaporation of soil moisture and protect the roots from extreme temperatures because blueberry plants have a shallow root system [19]. Messiga et al. [13] found that ammonium sulfate fertilizer applications above recommended $\mathrm{N}$ rates increased $\mathrm{NO}_{3}{ }^{-}-\mathrm{N}$ concentrations in the $0-30 \mathrm{~cm}$ soil layer by 2.6. to 3.6 times under fertigation (FERT), while $\mathrm{NH}_{4}{ }^{+}-\mathrm{N}$ concentrations increased in the sawdust mulch layer by 1.9 times. In general, when $\mathrm{N}$ input is greater than the optimal rate, yield may not increase further, but nutrient leaching may increase linearly or exponentially [20].

The shallow and confined root system of blueberry plants restricts their capacity to take up water from the soil and therefore irrigation is a key factor in the growth and production [19]. Drip irrigation is common in blueberry plantings and it is efficient because it reduces the amount of water required compared to overhead sprinklers [19]. However, irrigation can contribute to nutrient leaching, causing $\mathrm{NO}_{3}{ }^{-}-\mathrm{N}, \mathrm{NH}_{4}{ }^{+}-\mathrm{N}$ and $\mathrm{SO}_{4}{ }^{2-}-\mathrm{S}$ derived from ammonium sulfate fertilizer to drip downward through the soil profile and pose a great threat to the quality of groundwater [21]. Drip irrigation is also suitable for fertigation, but studies have shown that nutrient leaching can be increased with fertigation because dissolved nutrients move easily through the soil with water [13]. Ehret et al. [22] showed that $\mathrm{NH}_{4}{ }^{+}$leaching increases greatly in blueberry planting with fertigation, especially at higher rates, because of the ability to move quickly through the layer of sawdust mulch.

In a recent study, we showed that the use of ammonium sulfate fertilizer with fertigation above recommended rates can cause berry yield and soil $\mathrm{pH}$ to decrease, as well as increases in soil EC [13]. How nutrient leaching is influenced by $\mathrm{N}$ fertilizer rates and application methods and 
whether decreased berry yield trends with $\mathrm{N}$ applications above recommended $\mathrm{N}$ rates observed under fertigation will appear under broadcast (BROAD) with continuous ammonium sulfate fertilizer applications later in the production cycle is still unknown from this long-term blueberry planting. Adu-Gyamfy et al. [23] used ceramic cup lysimeters to assess nutrient leaching from corn production systems in northern Ghana. Similarly, Zvomuya et al. [24] studied nitrate leaching in potato fields in Minnesota. Ceramic cup lysimeters provide a way to assess nutrient leaching and these were considered in the present study. The objectives of this study were to (a) assess the effects of annual applications of ammonium sulfate fertilizer through fertigation and broadcast applications on nutrient leaching losses, including $\mathrm{NO}_{3}{ }^{-}-\mathrm{N}, \mathrm{NH}_{4}{ }^{+}-\mathrm{N}$ and $\mathrm{SO}_{4}{ }^{2-}-\mathrm{S}$ and (b) determine the links among chemical property changes in soil and leachates with berry yields.

\section{Materials and Methods}

\subsection{Site Description}

The long-term blueberry site was established in 2008 at Agassiz Research and Development Centre (Agriculture and Agri-Food Canada) $\left(49^{\circ} 14^{\prime} \mathrm{N}, 121^{\circ} 45^{\prime} \mathrm{W}\right)$. Several papers have already been published from this site on a wide range of topics $[13,18,22]$. The local climate of the Fraser Valley is characterized as moderate oceanic with relatively cool, dry summers and warm, rainy winters; the average annual rainfall is $1689 \mathrm{~mm}$, where $261.9 \mathrm{~mm}$ falls between May and July. The local climate occupies a narrow annual temperature range between $3.2^{\circ} \mathrm{C}$ in December and $18.7^{\circ} \mathrm{C}$ in August. The topography of the area is relatively flat with an average elevation of $7.6 \mathrm{~m}$ above sea level. The soil at the site is a silt loam soil of the Monroe series and is moderately well drained (Typic Dystroxerepts under the U.S. Soil Taxonomy [25]. Until 2006, the field received compost derived from lawn clippings and poultry and greenhouse vegetable waste. The chemical characteristics of the topsoil when the experiment was established were: $5.27 \%$ organic matter and $29 \mathrm{~kg} \mathrm{ha}^{-1}$ soil mineral $\mathrm{N}[13,22]$. Field preparation and planting occurred in the spring and fall, respectively, in 2008 [13].

\subsection{Experimental Design and Treatments}

Seven combinations of treatments, including an unfertilized control (CONT), three $\mathrm{N}$ fertilizer rates $(100 \%, 150 \%, 200 \%$ of recommended rates in the British Columbia Berry Production Guide [26]) and two application methods (broadcast (BROAD) and fertigation (FERT)), were compared. The seven combinations of treatments (CONT, BROAD-100, FERT-100, BROAD-150, FERT-150, BROAD-200 and FERT-200) were applied to a randomized complete block design with four replicates for a total of 28 experimental units. The experimental units consisted of seven plants, including five measurement plants and two guard plants at the edges of the plots. The $\mathrm{N}$ fertilizer used was ammonium sulfate (21-0-0). Nitrogen application via BROAD was applied at the surface of the sawdust mulch surrounding the base of the blueberry plants and occurred over a span of eight weeks, beginning in late April or early May. A total of three split applications were applied in which one BROAD application was equivalent to one third of the total annual $N$. Nitrogen applications via FERT began at bud break and were repeated every week (ending in late August or early September). Fifteen equal applications were used for FERT so that each application consisted of $1 / 15$ of the total annual N. Total $\mathrm{N}$ applications every year were $144 \mathrm{~kg} \mathrm{~N} \mathrm{ha}^{-1}$ for $100 \%$ (recommended rate, [26], $215 \mathrm{~kg} \mathrm{~N} \mathrm{ha}^{-1}$ for $150 \%$ and $287 \mathrm{~kg} \mathrm{~N} \mathrm{ha}^{-1}$ for 200\% [18]. Each treatment (FERT, BROAD and CONT) received an equal amount of water; however, FERT application and irrigation did not occur simultaneously, but were completed within $7 \mathrm{~h}$ periods of each other.

Fertigation and irrigation were applied through two lines of drip tape (DLT Heavywall Dripperline, Netafim, Fresno, CA, USA) equipped with emitters. Granular matrix sensors (Watermark Model 900 M, Irrometer Co., Riverside, CA, USA) were used to monitor soil moisture tension and EC-5 sensors (Decagon Devices Inc., Pullman, WA, USA) for soil water content. Plants are pruned according to industry standards every year [26]. Following the 2016 harvesting season, the plants were heavily 
pruned to rejuvenate the plantings. A honeybee hive was installed to encourage pollination and bird netting placed around the bushes to prevent berry loss. Pesticides were applied for weed, fungus (botrytis blossoms) and insect (Bruce spanworm (Operophtera bruceata) and European leafroller (Archips rosanus)) control [13,22].

\subsection{Leachate Samples}

Leachate samples were collected from all experimental plots using ceramic cup ( $0.1 \mathrm{MPa}$ air entry pressure) suction lysimeters (Soilmoisture Equipment Corp., Santa Barbara, CA, USA) during the periods of 30 March 2016-20 February 2017 and 22 March 2017-17 April 2018. The suction lysimeters were assembled in the laboratory by fixing the round bottom, porous ceramic cup to one end of a $60 \mathrm{~cm}$ polyvinyl chloride (PVC) tube [27]. One suction lysimeter was installed in the middle of each plot at a $76 \mathrm{~cm}$ depth below the soil surface, to capture residual nutrients leached from the rooting zone, as described by Zvomuya et al. [24]. Briefly, at the point of the installation, a hole was dug vertically at a $76 \mathrm{~cm}$ depth using an auger. Two hundred and fifty milliliters of silica flour were poured into the bottom of the hole to improve the hydraulic contact between the porous ceramic cup and the surrounding soil. The suction lysimeter was then inserted into the hole and the soil augured out was repacked and the lysimeter was sealed at the soil surface with bentonite to reduce water flow along the shaft.

To collect leachate samples, a suction pressure of $40 \mathrm{kPa}$ was applied with a hand pump and the lysimeters were sealed for $24 \mathrm{~h}$. Previous studies showed that a $40 \mathrm{kPa}$ vacuum was sufficient to create suction in the cup above that of the surrounding soil until the sample was extracted [24]. After $24 \mathrm{~h}$, leachate samples were collected from the lysimeters using the hand pump and $100 \mathrm{~mL}$ of the leachate was kept frozen until analysis.

\subsection{Sawdust Mulch and Soil Sampling}

Sawdust and soil samples were collected in fall 2018. The sawdust layer, approximately $10 \mathrm{~cm}$ thick, was collected by hand. Four soil cores $(2 \mathrm{~cm}$ diameter) were then collected from between the measurement plants, along the dripline, at depths of $0-30 \mathrm{~cm}$ and $30-60 \mathrm{~cm}$. The field moist sawdust and soil samples were composited on-site, air-dried, sieved $(2 \mathrm{~mm})$ and stored at room temperature until analysis.

\subsection{Berry Yield}

Yield data presented in this study represent three consecutive years of harvest starting in 2016 and ending in 2018. Yield data from previous years are presented elsewhere [13,22]. Berries were harvested twice a year from the five measurement plants of each experimental plot and weighed for fresh berry yield [13]. Berries were hand-picked in late June for the first harvest and mid-July for the second harvest. During the second harvest, unripe fruits were hand-picked from the bushes to avoid a third picking, due to limited resources. The sum of berry yields in the first and second harvests, including unripe fruits, represents total berry yield.

\subsection{Chemical Analysis}

The concentrations of $\mathrm{NO}_{3}{ }^{-}-\mathrm{N}$ and $\mathrm{NH}_{4}{ }^{+}-\mathrm{N}$ in the leachate samples were analyzed by the colorimetric method using a flow injection analyzer (Tecator FIAStar 2010) as described by Maynard et al. [28]. The concentration of $\mathrm{SO}_{4}{ }^{-}-\mathrm{S}$ in the leachate samples was analyzed by the turbidimetric method [29]. The $\mathrm{pH}$ and $\mathrm{EC}$ of the leachate samples were measured directly in a $20 \mathrm{~mL}$ volume using a $\mathrm{pH} / \mathrm{EC}$ meter (YSI MultiLab IDS 4010-3W). Soil mineral $\mathrm{N}\left(\mathrm{NO}_{3}{ }^{-}-\mathrm{N}\right.$ and $\left.\mathrm{NH}_{4}{ }^{+}-\mathrm{N}\right)$ was analyzed by extracting $5 \mathrm{~g}$ subsamples of air-dried soil and $5 \mathrm{~g}$ of sawdust using $2 \mathrm{M} \mathrm{KCl}$ in a 1:10 (w:v) ratio. The colorimetric analysis of the soil samples for $\mathrm{NO}_{3}{ }^{-}-\mathrm{N}$ and $\mathrm{NH}_{4}{ }^{+}-\mathrm{N}$ was performed using a flow injection analyzer [28]. A 1:1 (w/v) soil:solution ratio was used to measure the soil $\mathrm{pH}$ and EC of the air-dried samples in distilled water. 


\subsection{Statistical Analysis}

The SAS univariate procedure was used to test for normality and the analysis of variance (ANOVA) was performed with SAS Proc Mixed, version 9.3 [30] for all data. For all parameters, replicates and years were considered random and repeated effects, respectively. Treatments and two-way interactions (treatments for berry yield; treatments and treatments $\times$ sampling dates for leachate properties; treatments and treatments $\times$ depth for mineral $\mathrm{N}$ and soil properties) were considered fixed effects where appropriate. Differences among least square means (LSMEANS) for all treatment pairs were tested at a significance level of $p=0.05$. Where appropriate, LSMEANS were compared with a combination of orthogonal and polynomial contrasts: CONT versus ALL; FERT versus BROAD; linear and quadratic effects for $\mathrm{N}$ rates. Principal component analysis (PCA) was carried out using SAS Proc Princomp to establish the relationships between yields and chemical properties of soil and leachate.

\section{Results}

\subsection{Weather Conditions}

Total precipitation was $1546 \mathrm{~mm}$ during the 2016/17 period (March 2016-February 2017) and $1610 \mathrm{~mm}$ during the 2017/18 period (March 2017-February 2018) (Figure 1). The growing season, from May to September, received $302 \mathrm{~mm}$ of rainfall during the 2016/17 period, but $232 \mathrm{~mm}$ during the 2017/18 period. More specifically, June with $83 \mathrm{~mm}$, July with $48 \mathrm{~mm}$ and August with $18 \mathrm{~mm}$ during the 2016/18 period received 2.0, 5.0 and 2.0 times more rainfall compared with the same months during the 2017/18 period, while May and September received similar rainfall during the two periods. For the non-growing season, (October to April), the 2016/17 period received $25 \mathrm{~mm}$ less precipitation than the 2017/18 period. More specifically, December with $90 \mathrm{~mm}$, January with $261 \mathrm{~mm}$ and February with $238 \mathrm{~mm}$ during the second period received 2.0, 2.3 and 1.5 times more precipitation compared with the same months of the 2016/17 period. In contrast, April 2017 received 3.0 times more precipitation compared with April 2016, while March 2017 received 2.8 times more precipitation compared with March 2018. The mean growing season air temperatures were $17.64^{\circ} \mathrm{C}$ and $17.36^{\circ} \mathrm{C}$ during the $2016 / 17$ and 2017/18 periods, respectively (Figure $1 \mathrm{a}, \mathrm{b}$ ). The mean non-growing season air temperatures were $5.37^{\circ} \mathrm{C}$ and $5.80^{\circ} \mathrm{C}$ during the $2016 / 17$ and the $2017 / 18$ periods, respectively.

\subsection{Concentrations of Nitrate, Ammonium and Sulfate in Leachate}

The concentrations of $\mathrm{NO}_{3}{ }^{-}-\mathrm{N}$ in the leachate were influenced by $\mathrm{N}$ application methods and rates, but the extent varied with sampling periods (Table 1). In the 2016/17 period, concentrations of $\mathrm{NO}_{3}{ }^{-}-\mathrm{N}>10 \mathrm{mg} \mathrm{L}^{-1}$, which are equivalent to the Canadian critical limit of $\mathrm{NO}_{3}{ }^{-}-\mathrm{N}$ in drinking water [7], were measured throughout sampling dates for FERT-based applications and BROAD-150 and BROAD-200 (Figure 2a). Concentrations of $\mathrm{NO}_{3}{ }^{-}-\mathrm{N}>100 \mathrm{mg} \mathrm{L}^{-1}$ were measured between 30 March and 21 November for FERT-200 (102.75-203.14 $\left.\mathrm{mg} \mathrm{L}^{-1}\right), 9$ May to 19 September for FERT-150 (117.71-152.51 $\mathrm{mg} \mathrm{L}^{-1}$ ) and 4 July to 1st August for FERT-100 (113.4 $\mathrm{mg} \mathrm{L}^{-1}$ ) (Figure 2a). In the 2017/18 period, concentrations of $\mathrm{NO}_{3}{ }^{-}-\mathrm{N}>10 \mathrm{mg} \mathrm{L}^{-1}$ were measured for FERT-based and BROAD-200 applications between 23 April 2017 and 17 April 2018 (Figure 2b). For BROAD-150, concentrations of $\mathrm{NO}_{3}{ }^{-}-\mathrm{N}>10 \mathrm{mg} \mathrm{L}^{-1}$ were measured between 21 November and 17 April 2018 (11.57-35.33 $\mathrm{mg} \mathrm{L}^{-1}$ ) and 7 May and 31 July $2017\left(10.25-13.75 \mathrm{mg} \mathrm{L}^{-1}\right)$, while this was observed between 21 November and 16 January 2018 (10.78-11.72 $\left.\mathrm{mg} \mathrm{L}^{-1}\right)$ for BROAD-100 and between 23 April and 31 July 2017 (12.57-25.29 $\mathrm{mg} \mathrm{L}^{-1}$ ) (Figure 2b). Concentrations of $\mathrm{NO}_{3}{ }^{-}-\mathrm{N}>100 \mathrm{mg} \mathrm{L}^{-1}$ were measured between 3rd June and 31 July 2017 for FERT-200 (101.82-138.58 mg L $\left.{ }^{-1}\right)$ and 31 July 2017 for FERT-150 (105.79 mg L L $^{-1}$ ). CONT had a lower concentration of $\mathrm{NO}_{3}{ }^{-}-\mathrm{N}$ compared with all the other $\mathrm{N}$ application rates and BROAD-based application had lower $\mathrm{NO}_{3}{ }^{-}-\mathrm{N}$ levels compared with FERT-based applications (Table 1 ). 

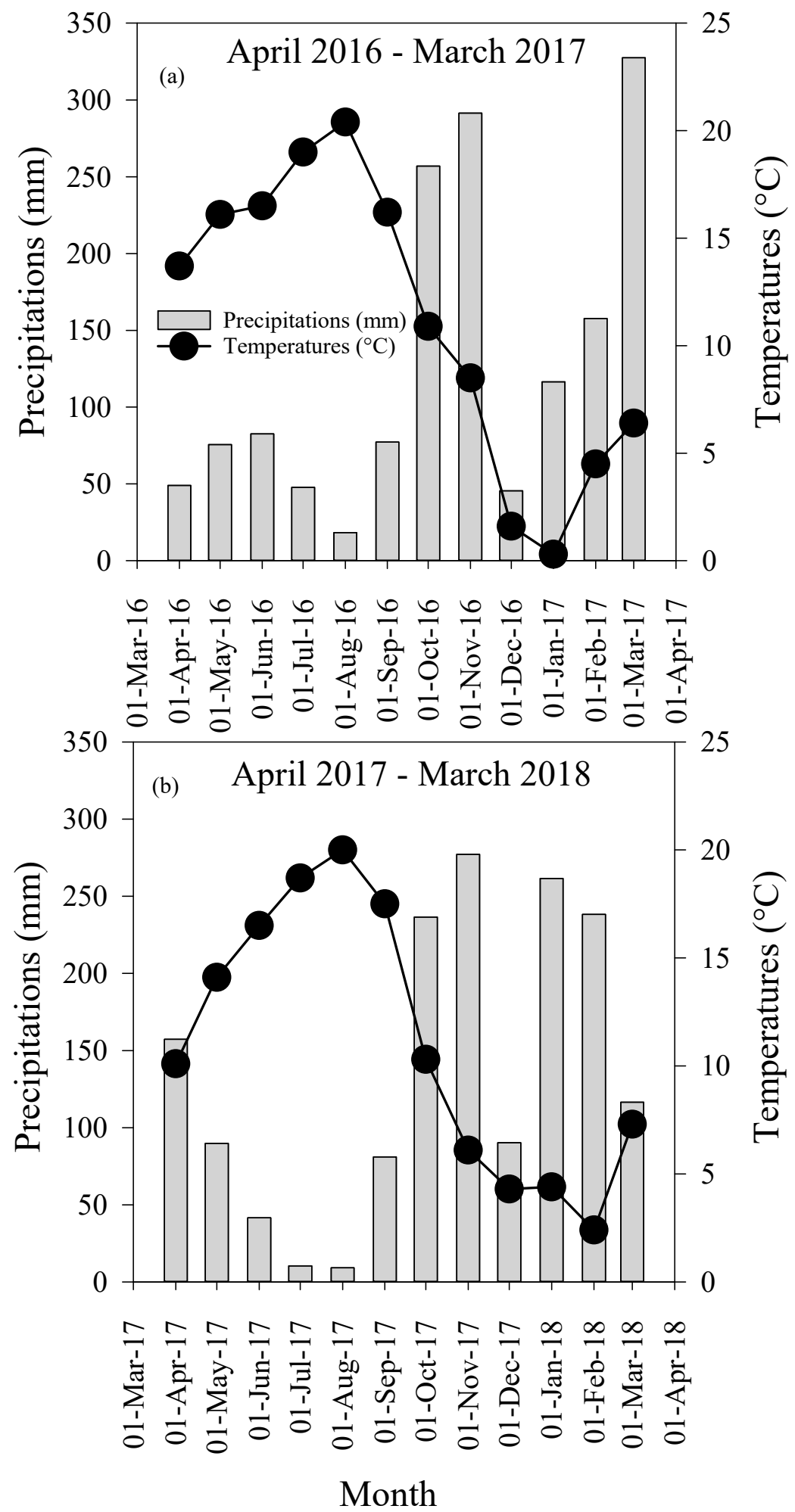

Figure 1. Average monthly precipitation and air temperatures during the periods (a) April 2016-March 2017 and (b) April 2017-March 2018. 
Table 1. Results of ANOVA for chemical properties of leachate water collected in lysimeters ( $30 \mathrm{~cm}$ depth) in the long-term blueberry experiment during the period March 2016 and April 2018 ( $\mathrm{n}=420$ and 555 for March 2016-February 2017 and March 2017-April 2018, respectively).

\begin{tabular}{|c|c|c|c|c|c|c|c|c|c|c|}
\hline & \multicolumn{5}{|c|}{ March 2016-February 2017} & \multicolumn{5}{|c|}{ March 2017-April 2018} \\
\hline & $\begin{array}{l}\mathrm{NO}_{3}^{--N} \\
\left(\mathrm{mg} \mathrm{L}^{-1}\right)\end{array}$ & $\begin{array}{l}\mathrm{NH}_{4}{ }^{+}-\mathrm{N} \\
\left(\mathrm{mg} \mathrm{L}^{-1}\right)\end{array}$ & $\begin{array}{c}\mathrm{SO}_{4}^{--S} \\
\left(\mathrm{mg} \mathrm{L}^{-1}\right)\end{array}$ & $\mathrm{pH}$ & $\begin{array}{c}E C^{1} \\
\left(\mu S \mathrm{~cm}^{-1}\right)\end{array}$ & $\begin{array}{l}\mathrm{NO}_{3}^{--N} \\
\left(\mathrm{mg} \mathrm{L}^{-1}\right)\end{array}$ & $\begin{array}{l}\mathrm{NH}_{4}^{+}-\mathrm{N} \\
\left(\mathrm{mg} \mathrm{L}^{-1}\right)\end{array}$ & $\begin{array}{c}\mathrm{SO}_{4}^{--S} \\
\left(\mathrm{mg} \mathrm{L}^{-1}\right)\end{array}$ & $\mathrm{pH}$ & $\begin{array}{c}E C^{1} \\
\left(\mu \mathrm{cm}^{-1}\right)\end{array}$ \\
\hline Sources of variation & \multicolumn{10}{|c|}{$p$ values $^{2}$} \\
\hline Treatment $(\mathrm{T})$ & $<0.001$ & $<0.001$ & $<0.001$ & $<0.001$ & $<0.001$ & $<0.001$ & $<0.001$ & $<0.001$ & $<0.001$ & $<0.001$ \\
\hline Sampling periods (SP) & $<0.001$ & $<0.001$ & $<0.001$ & $<0.001$ & $<0.001$ & $<0.001$ & $<0.001$ & $<0.001$ & $<0.001$ & $<0.001$ \\
\hline $\mathrm{T} \times \mathrm{SP}$ & $<0.001$ & $<0.001$ & $<0.001$ & $<0.001$ & $<0.001$ & $<0.001$ & $<0.001$ & $<0.001$ & $<0.001$ & $<0.001$ \\
\hline Contrast & & & & & & & & & & \\
\hline CONT vs. All & $<0.001$ & 0.146 & 0.001 & $<0.001$ & $<0.001$ & $<0.001$ & 0.034 & $<0.001$ & 0.002 & $<0.001$ \\
\hline FERT vs. BROAD & $<0.001$ & 0.001 & $<0.001$ & $<0.001$ & $<0.001$ & $<0.001$ & $<0.001$ & $<0.001$ & $<0.001$ & $<0.001$ \\
\hline Linear & 0.001 & 0.852 & 0.032 & 0.001 & 0.003 & 0.004 & 0.694 & 0.003 & 0.004 & $<0.001$ \\
\hline Quadratic & $<0.001$ & 0.019 & 0.004 & $<0.001$ & $<0.001$ & 0.008 & 0.002 & 0.002 & $<0.002$ & 0.006 \\
\hline
\end{tabular}

${ }^{1}$ Electrical conductivity; ${ }^{2}$ probability values. 

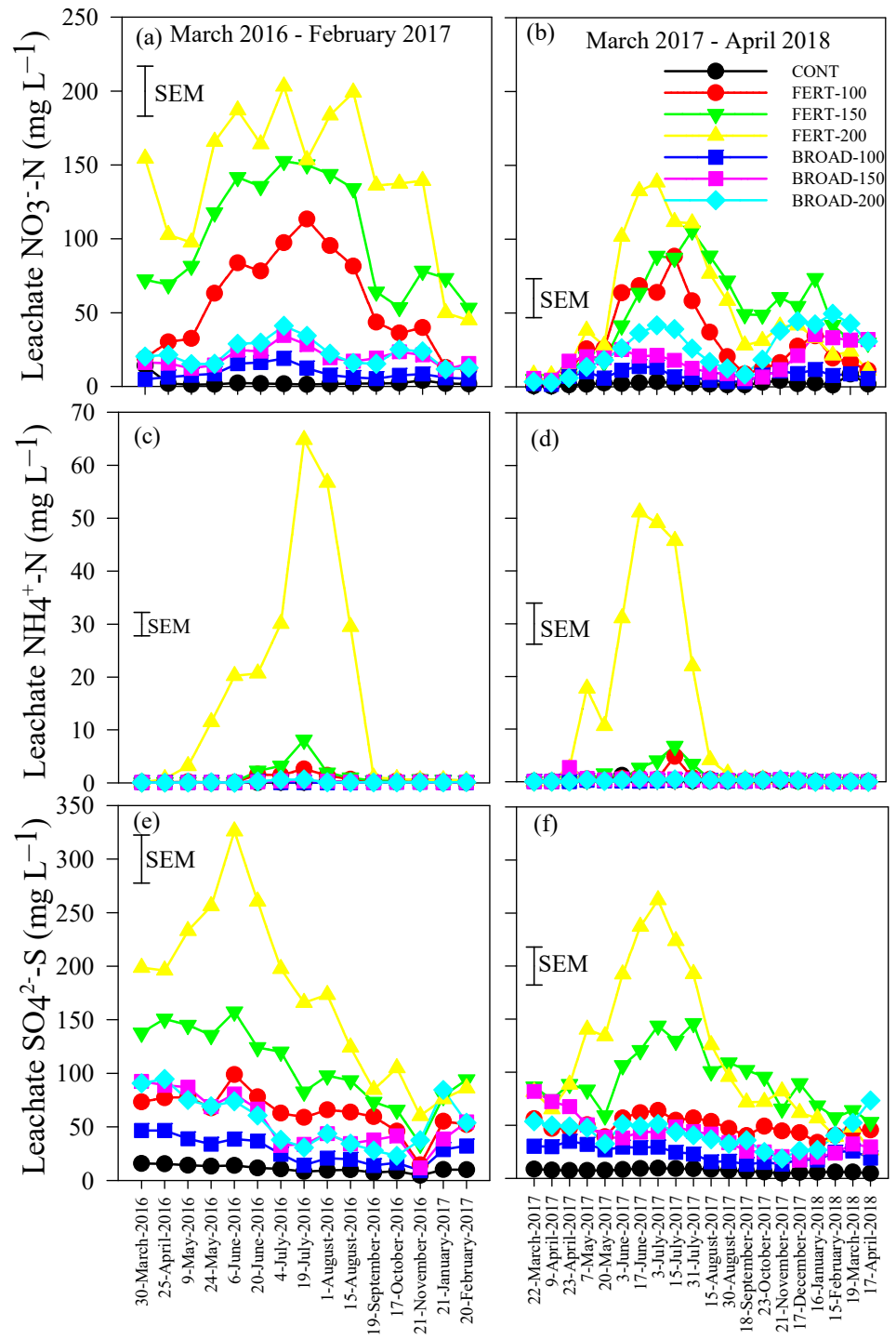

Sampling date

Figure 2. Concentrations of $(\mathbf{a}, \mathbf{b})$ nitrate nitrogen $\left(\mathrm{NO}_{3}-\mathrm{N}\right),(\mathbf{c}, \mathbf{d})$ ammonium nitrogen $\left(\mathrm{NH}_{4}-\mathrm{N}\right)$ and $(\mathbf{e}, \mathbf{f})$ sulfate sulfur $\left(\mathrm{SO}_{4}-\mathrm{S}\right)$ in the leachate collected at $76 \mathrm{~cm}$ soil depth with annual applications of $\mathrm{N}$ through the fertigation (FERT-100, 100\%; FERT-150, 150\%; FERT-200, 200\%) and broadcast (BROAD-100, 100\%; BROAD-150, 150\%; BROAD-200, 200\%) methods to highbush blueberry (Vaccinium corymbosum) for two consecutive years (March 2016-February 2017 and March 2017-April 2018). Error bars represent the standard errors of the means (SEM) for comparing all values $(n=420$ and $d f=294)$.

The concentration of $\mathrm{NH}_{4}{ }^{+}-\mathrm{N}$ in the leachate was also influenced by $\mathrm{N}$ application methods and rates, but the extent varied with sampling dates (Table 1; significant interactions). In the 2016/17 period, concentrations of $\mathrm{NH}_{4}{ }^{+}-\mathrm{N}>1.00 \mathrm{mg} \mathrm{L}^{-1}$, which can be toxic to aquatic and semiaquatic plant species [10], were measured between 20 June and 1st August 2016 for FERT-100 with a peak at $2.61 \mathrm{mg}$ $\mathrm{L}^{-1}$ and FERT-150 with a peak at $8.12 \mathrm{mg} \mathrm{L}^{-1}$, but between 9 May and 19 September 2016 for FERT-200 with a peak at $64.78 \mathrm{mg} \mathrm{L}^{-1}$ (Figure 2c). In the 2017/18 period, concentrations of $\mathrm{NH}_{4}{ }^{+}-\mathrm{N}>1.00 \mathrm{mg} \mathrm{L}^{-1}$ were measured on 15 July 2017 for FERT-100 with a peak at $4.82 \mathrm{mg} \mathrm{L}^{-1}$, between 20 May and 31 July 2017 for FERT-150 with a peak at $6.77 \mathrm{mg} \mathrm{L}^{-1}$, but between 23 April and 30 August 2017 for FERT-200 with a peak at $51.11 \mathrm{mg} \mathrm{L}^{-1}$ (Figure 2d). The concentrations of $\mathrm{NH}_{4}{ }^{+}-\mathrm{N}$ remained $<1.00 \mathrm{mg} \mathrm{L}^{-1}$ for the other $\mathrm{N}$ applications throughout the two sampling periods. CONT had a lower concentration of 
$\mathrm{NH}_{4}{ }^{+}-\mathrm{N}$ compared with all the other $\mathrm{N}$ application rates and BROAD-based applications had lower $\mathrm{NH}_{4}{ }^{+}-\mathrm{N}$ levels compared with FERT-based applications (Table 1).

The concentrations of $\mathrm{SO}_{4}{ }^{-}-\mathrm{S}$ in the leachate was influenced by $\mathrm{N}$ applications, but the extent varied with time in 2016/17 and 2017/18 (Table 1). In the 2016/17 period, the concentrations of $\mathrm{SO}_{4}{ }^{-}-\mathrm{S}$ varied between $4.70 \mathrm{mg} \mathrm{L}^{-1}$ for CONT on 21 November 2016 and $326 \mathrm{mg} \mathrm{L}^{-1}$ for FERT-200 on 6th June 2016 (Figure 2e). Concentrations $>100 \mathrm{mg} \mathrm{L}^{-1}$ were measured between 30 March and 4 July 2016 for FERT-150 (120.00-157.50 $\mathrm{mg} \mathrm{L}^{-1}$ ) and between 30 March and 17 October 2016 for FERT-200 (104.90-326.00 $\left.\mathrm{mg} \mathrm{L}^{-1}\right)$. In the 2017/18 period, the concentrations of $\mathrm{SO}_{4}{ }^{-}-\mathrm{S}$ varied between $4.60 \mathrm{mg} \mathrm{L}^{-1}$ for CONT on 21 November and $262.10 \mathrm{mg} \mathrm{l}^{-1}$ on 3 July 2017 (Figure 2f). Concentrations $>100 \mathrm{mg} \mathrm{L}^{-1}$ were measured between $3^{\text {rd }}$ June and 18 September 2017 for FERT-150 $\left(101.80-146.03 \mathrm{mg} \mathrm{L}^{-1}\right)$ and between 7th May and 15 August 2017 for FERT-200 (125.70-262.10 mg L ${ }^{-1}$ ). CONT had a lower concentration of $\mathrm{SO}_{4}{ }^{-}-\mathrm{S}$ compared with all the other $\mathrm{N}$ application rates and BROAD-based applications had lower $\mathrm{SO}_{4}{ }^{-}-\mathrm{S}$ levels compared with FERT-based applications (Table 1).

\subsection{Acidity and Electrical Conductivity of Leachate}

The $\mathrm{pH}$ of leachate was influenced by $\mathrm{N}$ application methods and rates, but the extent varied with the sampling periods (Table 1). During the 2016/17 period, the $\mathrm{pH}$ of leachate varied between 3.52 (FERT-200) on 15 August 2016 and 6.97 (CONT) on 21 January 2017 (Figure 3a). The pH of leachate ranged between 6.10 and 5.16 for FERT-100, 4.85 and 4.03 for FERT-150 and 4.21 and 3.52 for FERT-200 and 5.80 and 6.45 for BROAD-200 (Figure 3a). The $\mathrm{pH}$ values $>6.00$ were measured under CONT, BROAD-100 and BROAD-150 (Figure 3a). During the 2017/18 period, the $\mathrm{pH}$ of leachate varied between 3.22 for FERT-200 on 17 December 2017 and 7.30 for CONT on 22 March 2017 (Figure 3b). The $\mathrm{pH}$ values of the leachate ranged between 5.67 and 4.52 for FERT-100, 3.56 and 4.32 for FERT-150 and 3.90 and 3.22 for FERT-200 (Figure $3 \mathrm{~b}$ ). The $\mathrm{pH}$ values were $>6.05$ under CONT, while $\mathrm{pH}$ values ranging between 5.42 and 6.81 were measured in leachate collected under BROAD-based treatments (Figure $3 b$ ). CONT had higher $\mathrm{pH}$ compared with all the other $\mathrm{N}$ application rates and BROAD-based applications had higher $\mathrm{pH}$ compared with FERT-based applications (Table 1).

The EC of leachate was influenced by $\mathrm{N}$ application methods and rates, but the extent varied with time in 2016/17 and 2017/18 (Table 1). In the 2016/17 period, EC values $>760 \mu \mathrm{S} \mathrm{cm}^{-1}$ were measured in the leachate collected from 9 May 2016 and 19 September 2016 under FERT-100 $\left(767-1381 \mu \mathrm{S} \mathrm{cm}^{-1}\right)$, and on 20 February 2017 under FERT-150 $(943-1867 \mu \mathrm{S} \mathrm{cm}-1)$ and FERT-200 $\left(872-2900 \mu \mathrm{S} \mathrm{cm}^{-1}\right)$ (Figure 3c). In the 2017/18 period, EC values $>760 \mu \mathrm{S} \mathrm{cm}^{-1}$ [13] were measured in the leachate collected from 20 May and 31 July 2017 under FERT-100 $\left(860-1078 \mu \mathrm{S} \mathrm{cm}^{-1}\right)$ and 16 January 2018 under FERT-150 $\left(850-1903 \mu \mathrm{S} \mathrm{cm}^{-1}\right)$, and as early as 23 April and 30 August 2017 under FERT-200 $\left(760-2510 \mu \mathrm{S} \mathrm{cm}^{-1}\right)$ (Figure 3d). The EC of leachate collected under CONT and BROAD-based N applications remained lower than $760 \mu \mathrm{S} \mathrm{cm}^{-1}$ (Figure 3c,d). CONT had lower EC compared with all the other $\mathrm{N}$ application rates and BROAD-based applications had lower EC compared with FERT-based applications (Table 1). 

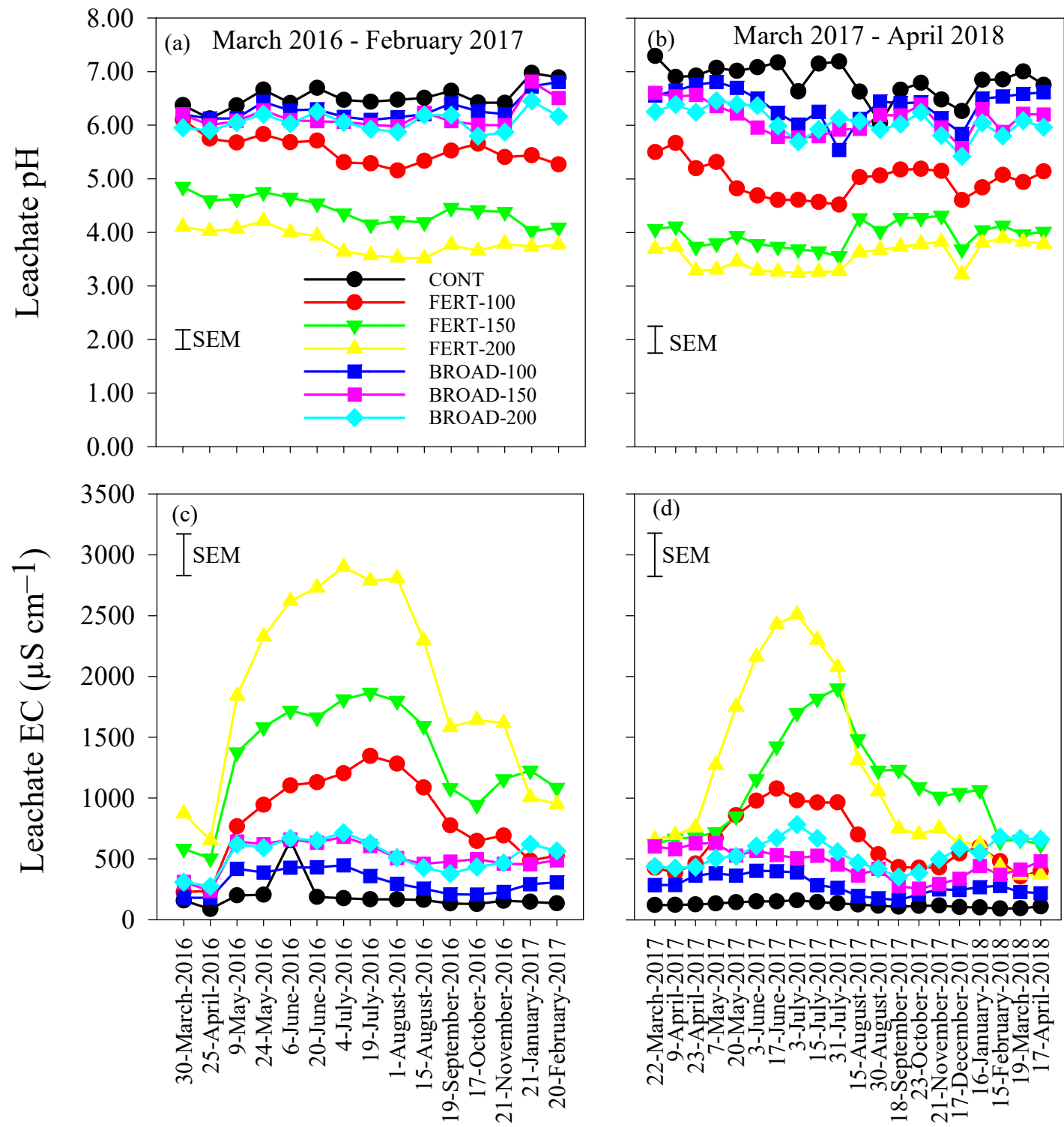

Sampling date

Figure 3. (a,b) Acidity $(\mathrm{pH})$ and (c,d) electrical conductivity $(\mathrm{EC})$ of leachate collected at $76 \mathrm{~cm}$ soil depth with annual applications of N through fertigation (FERT-100, 100\%; FERT-150, 150\%; FERT-200, 200\%) and broadcast (BROAD-100, 100\%; BROAD-150, 150\%; BROAD-200, 200\%) methods to highbush blueberry (Vaccinium corymbosum) for two consecutive years (March 2016-February 2017 and March 2017-April 2018). Error bars represent the standard errors of the means (SEM) for comparing all values $(\mathrm{n}=420$ and $\mathrm{df}=294)$.

\subsection{Ammonium, Nitrate and Mineral $N$ in the Soil}

The concentration of $\mathrm{NH}_{4}{ }^{+}-\mathrm{N}$ was significantly influenced by $\mathrm{N}$ application methods and rates, but the extent varied with soil depth $(p=0.002)$ (Table 2). A quadratic effect of the $\mathrm{N}$ application rates was observed. In the sawdust layer, the concentration of $\mathrm{NH}_{4}{ }^{+}-\mathrm{N}$ varied from $14.62 \mathrm{mg} \mathrm{kg}^{-1}$ under CONT to $395.32 \mathrm{mg} \mathrm{kg}^{-1}$ under BROAD-150; in the 0-30 cm depth, the concentration of $\mathrm{NH}_{4}{ }^{+}-\mathrm{N}$ varied from $7.02 \mathrm{mg} \mathrm{kg}^{-1}$ under CONT to $21.07 \mathrm{mg} \mathrm{kg}^{-1}$ under BROAD-200; in the 30-60 $\mathrm{cm}$ soil depth, the concentration of $\mathrm{NH}_{4}{ }^{+}-\mathrm{N}$ varied from $25.05 \mathrm{mg} \mathrm{kg}^{-1}$ under CONT to $33.08 \mathrm{mg} \mathrm{kg}^{-1}$ under FERT-200 (Figure 4a). 
Table 2. Results of ANOVA for the effects of nitrogen applications through fertigation (FERT) and broadcast (BROAD) methods and soil depth (sawdust layer, $0-30 \mathrm{~cm}$ and $30-60 \mathrm{~cm}$ ) on the concentrations of ammonium $\mathrm{N}\left(\mathrm{NH}_{4}{ }^{+}-\mathrm{N}\right)$, nitrate $\mathrm{N}\left(\mathrm{NO}_{3}{ }^{-}-\mathrm{N}\right)$, mineral $\mathrm{N}\left(\mathrm{NH}_{4}{ }^{+}-\mathrm{N}+\mathrm{NO}_{3}{ }^{-}-\mathrm{N}\right)$, soil $\mathrm{pH}$ and electrical conductivity (EC) collected in fall 2018 in a highbush blueberry (Vaccinium corymbosum) $(\mathrm{n}=84)$.

\begin{tabular}{|c|c|c|c|c|c|}
\hline & $\begin{array}{c}\mathrm{NH}_{4}^{+}-\mathrm{N} \\
\left(\mathrm{mg} \mathrm{kg}^{-1}\right)\end{array}$ & $\begin{array}{c}\mathrm{NO}_{3}^{--}-\mathrm{N} \\
\left(\mathrm{mg} \mathrm{kg}^{-1}\right)\end{array}$ & $\begin{array}{l}\text { Mineral N }\left(\mathrm{NH}_{4}^{+}-\mathrm{N}\right. \\
\left.+\mathrm{NO}_{3}{ }^{-}-\mathrm{N}, \mathrm{mg} \mathrm{kg}^{-1}\right)\end{array}$ & $\mathrm{pH}$ & EC \\
\hline Sources of variation & & & $p$ values ${ }^{1}$ & & \\
\hline $\mathrm{N}$ applications $(\mathrm{N})$ & 0.039 & $<0.001$ & 0.016 & $<0.001$ & $<0.001$ \\
\hline Depth & $<0.001$ & $<0.001$ & $<0.001$ & $<0.001$ & $<0.001$ \\
\hline $\begin{array}{c}\mathrm{N} \text { applications } \times \text { Depth } \\
\text { Contrast }\end{array}$ & 0.002 & 0.020 & 0.002 & $<0.001$ & $<0.001$ \\
\hline CONT $^{2}$ vs. All & 0.882 & 0.005 & 0.114 & 0.003 & 0.045 \\
\hline FERT vs. BROAD & 0.029 & $<0.001$ & 0.881 & $<0.001$ & 0.007 \\
\hline Linear & 0.477 & 0.045 & 0.015 & $<0.001$ & 0.001 \\
\hline Quadratic & 0.676 & 0.025 & 0.097 & 0.002 & 0.027 \\
\hline
\end{tabular}

${ }^{1}$ Probability values; ${ }^{2}$ control, $0 \mathrm{~kg} \mathrm{~N} \mathrm{ha}{ }^{-1}$.

The concentration of $\mathrm{NO}_{3}{ }^{-}-\mathrm{N}$ was significantly influenced by $\mathrm{N}$ application methods and rates, but the extent varied with soil depth $(p=0.020)$ (Table 2). A linear effect of the $\mathrm{N}$ application rates was observed. In the sawdust layer, the concentration of $\mathrm{NO}_{3}{ }^{-}-\mathrm{N}$ varied from $0.00 \mathrm{mg} \mathrm{kg}{ }^{-1}$ under CONT to $89.43 \mathrm{mg} \mathrm{kg}^{-1}$ under FERT-200; in the 0-30 $\mathrm{cm}$ soil depth, the concentration of $\mathrm{NO}_{3}{ }^{-}{ }_{-} \mathrm{N}$ varied from $0.00 \mathrm{mg} \mathrm{kg}^{-1}$ under CONT to $134.16 \mathrm{mg} \mathrm{kg}^{-1}$ under FERT-200; in the $30-60 \mathrm{~cm}$ soil depth, the concentration of $\mathrm{NO}_{3}{ }^{-}-\mathrm{N}$ varied from $0.16 \mathrm{mg} \mathrm{kg}^{-1}$ under CONT to $31.80 \mathrm{mg} \mathrm{kg}^{-1}$ under FERT-200 (Figure 4a). Orthogonal contrast comparisons showed that the concentrations of $\mathrm{NO}_{3}{ }^{-}-\mathrm{N}$ were lower under CONT compared with all $\mathrm{N}$ application rates, while the concentrations of $\mathrm{NO}_{3}{ }^{-}-\mathrm{N}$ were higher under FERT-based compared with BROAD-based (32.50 $\mathrm{mg} \mathrm{kg}^{-1}$ under sawdust, $31.95 \mathrm{mg} \mathrm{kg}^{-1}$ under 0-30 $\mathrm{cm}$ depth, and $5.15 \mathrm{mg} \mathrm{kg}^{-1}$ under 30-60 $\mathrm{cm}$ depth) treatments (Table 2).

The concentration of soil mineral $\mathrm{N}\left(\mathrm{NH}_{4}{ }^{+}-\mathrm{N}+\mathrm{NO}_{3}{ }^{-}-\mathrm{N}\right)$ was significantly influenced by $\mathrm{N}$ application methods and rates, but the extent varied with soil depth $(p=0.002)$. More specifically, there was a linear trend of soil mineral $\mathrm{N}$ with $\mathrm{N}$ application rates (Table 2). In the sawdust layer, the concentration of soil mineral $\mathrm{N}$ varied from $14.62 \mathrm{mg} \mathrm{kg}^{-1}$ (CONT) to $433.38 \mathrm{mg} \mathrm{kg}^{-1}$ (BROAD-150); in the $0-30 \mathrm{~cm}$ soil depth, the concentration of soil mineral $\mathrm{N}$ varied from $7.02 \mathrm{mg} \mathrm{kg}^{-1}$ (CONT) to $153.94 \mathrm{mg} \mathrm{kg}^{-1}$ (FERT-200); in the 30-60 $\mathrm{cm}$ soil depth, the concentration of soil mineral $\mathrm{N}$ varied from $25.20 \mathrm{mg} \mathrm{kg}^{-1}$ (CONT) to $64.88 \mathrm{mg} \mathrm{kg}^{-1}$ (FERT-200) (Figure 4c). 

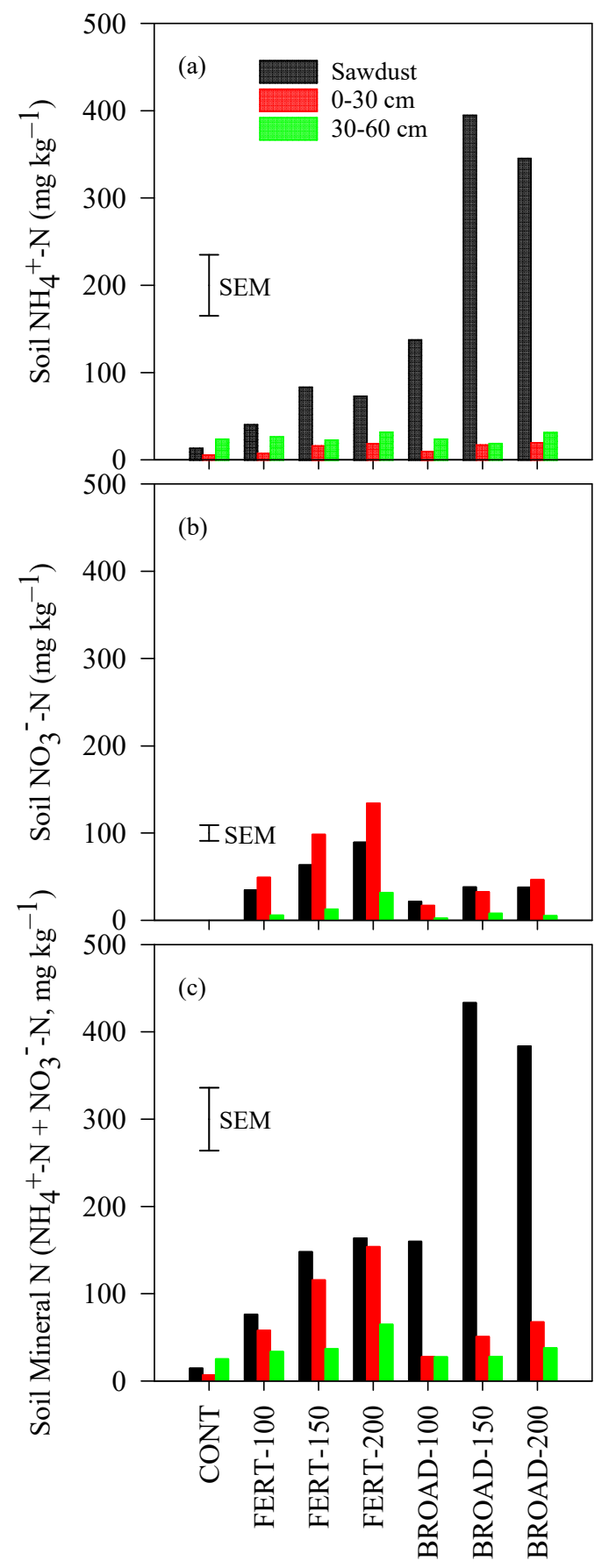

Treatment

Figure 4. Concentrations of (a) Ammonium nitrogen $\left(\mathrm{NH}_{4}{ }^{+}-\mathrm{N}\right),(\mathbf{b})$ nitrate nitrogen $\left(\mathrm{NO}_{3}{ }^{-}-\mathrm{N}\right)$ and (c) mineral nitrogen $\left(\mathrm{NH}_{4}{ }^{+}-\mathrm{N}+\mathrm{NO}_{3}{ }^{-}-\mathrm{N}\right)$ at $0-30 \mathrm{~cm}$ and 30-60 $\mathrm{cm}$ soil depth and in the sawdust mulch layer with annual applications of $\mathrm{N}$ through fertigation (FERT-100, 100\%; FERT-150, 150\%; FERT-200, 200\%) and broadcast (BROAD-100, 100\%; BROAD-150, 150\%; BROAD-200, 200\%) methods to highbush blueberry (Vaccinium corymbosum) in fall 2018. Error bars represent the standard errors of the means (SEM) for comparing all values $(n=28$ and $d f=21)$.

\subsection{Acidity and Electrical Conductivity in the Soil}

The soil $\mathrm{pH}$ was significantly influenced by $\mathrm{N}$ rates, but the extent varied with depth $(p<0.001)$. More specifically, there was a linear trend of soil $\mathrm{pH}$ with $\mathrm{N}$ application rates (Table 2). In the sawdust layer, soil $\mathrm{pH}$ varied from 5.62 (CONT) to 4.00 (FERT-200); In the 0-30 cm depth, soil $\mathrm{pH}$ varied from 
5.97 (CONT) to 4.04 (FERT-200); and in the $30-60 \mathrm{~cm}$ depth, soil $\mathrm{pH}$ varied from 6.17 (CONT) to 4.48 (FERT-200) (Figure 5a). Orthogonal contrast comparisons showed that soil $\mathrm{pH}$ remained high under CONT compared with all $\mathrm{N}$ treatments (Table 2), while FERT-based treatments had lower $\mathrm{pH}$ values (soil pH was 4.22, 4.28 and 4.72 in the sawdust, 0-30 cm depth and 30-60 cm depth, respectively) compared with BROAD-based treatments (soil pH was 4.32, 5.10 and 5.58 in the sawdust, $0-30 \mathrm{~cm}$ depth and 30-60 cm depth, respectively) (Figure 5a).
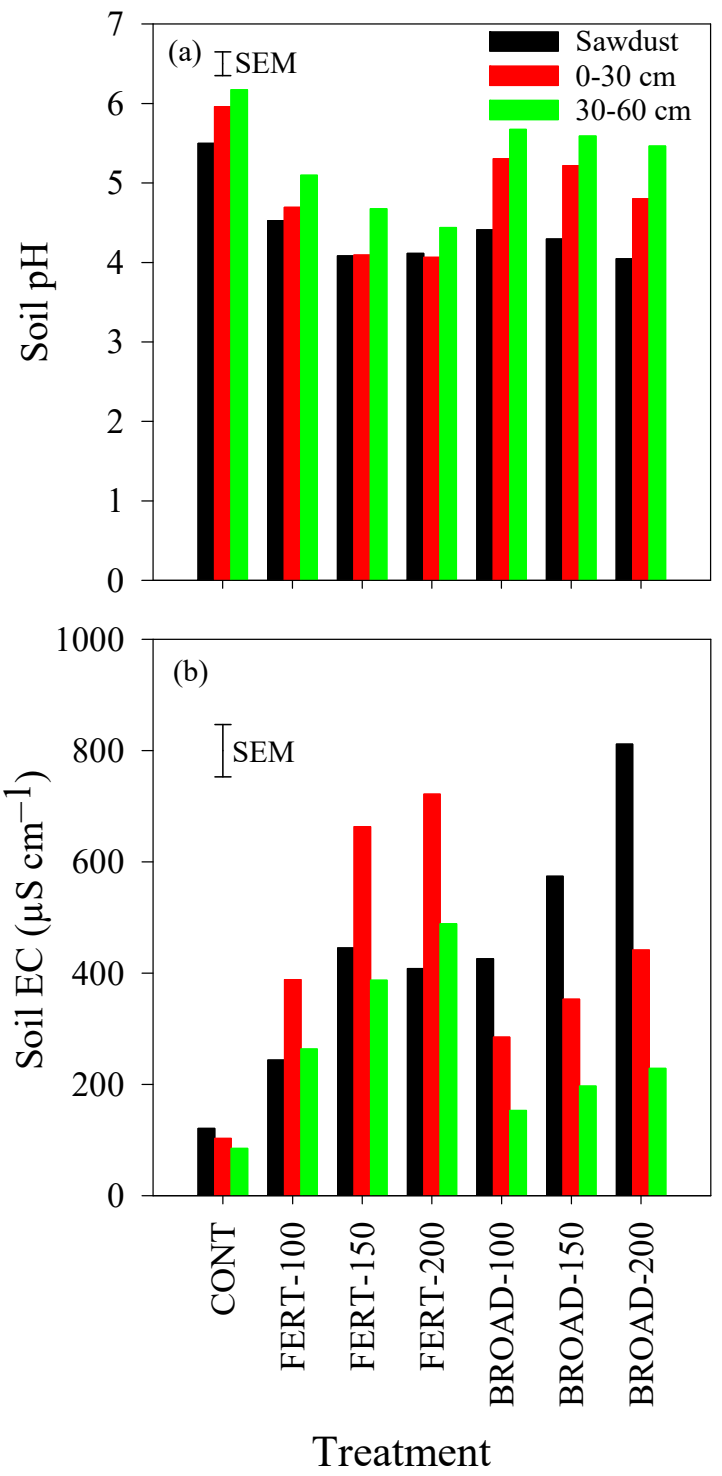

Figure 5. (a) Soil pH and (b) electrical conductivity (EC) at 0-30 $\mathrm{cm}$ and 30-60 $\mathrm{cm}$ soil depth and in the sawdust mulch layer with annual applications of N through fertigation (FERT-100, 100\%; FERT-150, 150\%; FERT-200, 200\%) and broadcast (BROAD-100, 100\%; BROAD-150, 150\%; BROAD-200, 200\%) methods to highbush blueberry (Vaccinium corymbosum) in fall 2018. Error bars represent the standard errors of the means (SEM) for comparing all values $(n=28$ and $\mathrm{df}=21)$.

Soil EC was significantly influenced by $\mathrm{N}$ rates, but the extent varied with depth $(p<0.001)$. More specifically, there was a linear trend of soil EC with $\mathrm{N}$ application rates (Table 2). In the sawdust layer, soil EC varied from $125.2 \mu \mathrm{S} \mathrm{cm}^{-1}$ (CONT) to $724.5 \mu \mathrm{S} \mathrm{cm}{ }^{-1}$ (BROAD-200); in the 0-30 cm depth, soil EC varied from $110.8 \mu \mathrm{S} \mathrm{cm}^{-1}$ (CONT) to $789.3 \mu \mathrm{S} \mathrm{cm}^{-1}$ (FERT-200); and in the 30-60 $\mathrm{cm}$ depth, soil EC varied from $96.2 \mu \mathrm{S} \mathrm{cm}^{-1}$ (CONT) to $518.3 \mu \mathrm{S} \mathrm{cm}^{-1}$ (FERT-200) (Figure 5b). Orthogonal contrast comparisons showed that soil EC remained low under CONT compared with all N treatments (Table 2), 
while FERT-based treatments had higher EC values (soil EC was 623.4 and 384.6 in the 0-30 cm depth and 30-60 cm depth, respectively) compared with BROAD-based treatments (soil EC was 361.3 and 193.7 in the 0-30 cm depth and 30-60 cm depth, respectively), except in the sawdust layer (Figure 5b).

\subsection{Blueberry Yields}

Berry yield was significantly influenced by $\mathrm{N}$ application methods and rates in $2016(p<0.001)$, but not in 2017 ( $p=0.929)$ or 2018 ( $p=0.336)$. In 2016, berry yield was 19,698 $\mathrm{kg} \mathrm{ha}^{-1}$ under CONT, which was significantly lower compared with $\mathrm{N}$ additions, except FERT-200 (Figure 6a). On average, berry yield increased by $66 \%$ with FERT-100, $43 \%$ with FERT-150 and only $12 \%$ with FERT-200 compared with CONT (Figure 6a). In the same year, berry yield increased by 35\% with BROAD-100 and $44 \%$ with BROAD-150 and BROAD-200 compared with CONT. Berry yield averaged $5278 \mathrm{~kg}$ $\mathrm{ha}^{-1}$ in 2017 and 18,817 kg ha ${ }^{-1}$ in 2018 (Figure 6b,c). A detailed examination of berry yield among $\mathrm{N}$ application methods and rates showed a decreasing trend with increasing $\mathrm{N}$ application with FERT- and BROAD-based treatments in 2017 and 2018. For example, berry yield was $5643 \mathrm{~kg} \mathrm{ha}^{-1}$ with FERT-150 but $4801 \mathrm{~kg} \mathrm{ha}^{-1}$ with FERT-200, and 6939 with BROAD-100 but $5186 \mathrm{~kg} \mathrm{ha}^{-1}$ with BROAD-200 (Figure 6b) in 2017. In addition, berry yield was $21,253 \mathrm{~kg} \mathrm{ha}^{-1}$ with FERT-100, but 14,979 $\mathrm{kg} \mathrm{ha}^{-1}$ with FERT-200, and 20,607 $\mathrm{kg} \mathrm{ha}^{-1}$ with BROAD-100, but 18,713 $\mathrm{kg} \mathrm{ha}^{-1}$ with BROAD-200 (Figure 6c) in 2018.
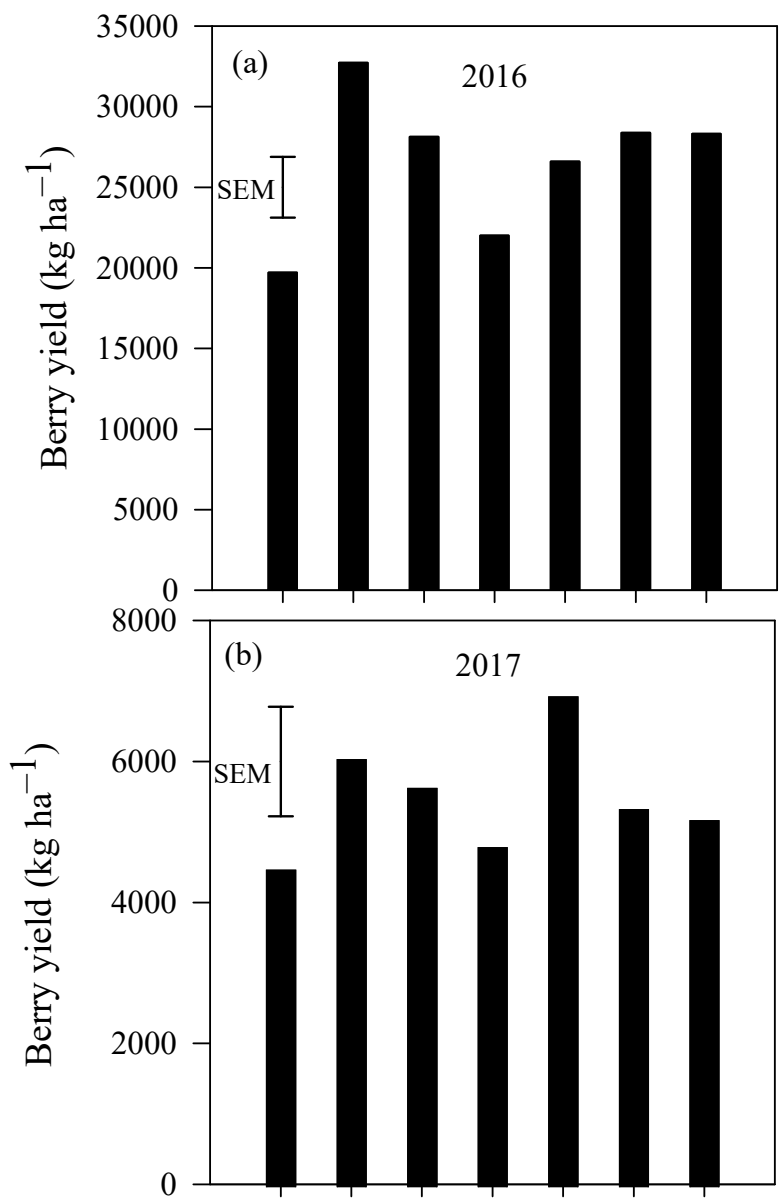

Figure 6. Cont. 


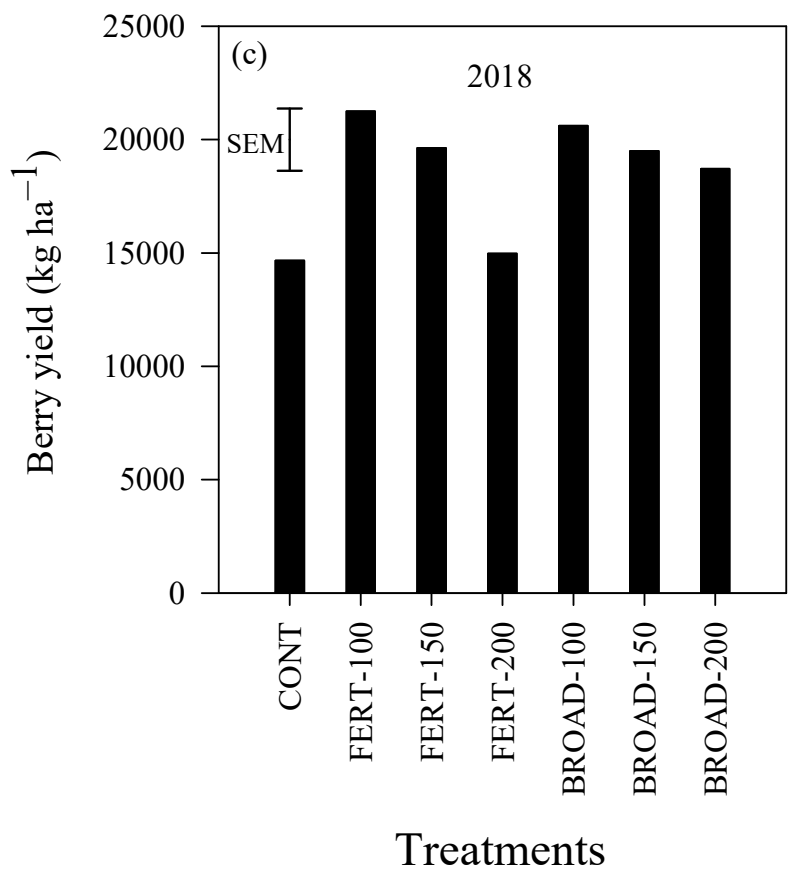

Figure 6. Total berry yield ( $\mathrm{kg} \mathrm{ha}^{-1}$ ) in (a) 2016, (b) 2017 and (c) 2018 with annual applications of N through fertigation (FERT-100, 100\%; FERT-150, 150\%; FERT-200, 200\%) and broadcast (BROAD-100, 100\%; BROAD-150, 150\%; BROAD-200, 200\%) methods to highbush blueberry (Vaccinium corymbosum). Error bars represent the standard errors of the means (SEM) for comparing all values $(n=28$ and $\mathrm{df}=21)$.

\subsection{Relationships between Soil And Leachate Chemical Properties and Berry Yield}

Principal component analysis (PCA) showed that $\mathrm{N}$ applications significantly influenced leachate and soil chemical properties, including $\mathrm{NH}_{4}{ }^{+}-\mathrm{N}, \mathrm{NO}_{3}{ }^{-}-\mathrm{N}, \mathrm{SO}_{4}{ }^{-}-\mathrm{S}, \mathrm{pH}, \mathrm{EC}$ and berry yield (Figure 7). The $\mathrm{N}$ applications were separated into three groups for their effects on chemical properties and yield, including (I) CONT, (II) FERT-100, FERT-150, BROAD-100, BROAD-150 and BROAD-200 and (III) FERT-200. Groups I and III negatively affected berry yields during the three years of study, but not group II. Pearson's correlation among berry yields and chemical properties of soil and leachate $\left(\mathrm{NH}_{4}{ }^{+}-\mathrm{N}, \mathrm{NO}_{3}{ }^{-}-\mathrm{N}, \mathrm{SO}_{4}{ }^{-}-\mathrm{S}, \mathrm{pH}, \mathrm{EC}\right)$ were in line with the results of PCA (Table S1). The concentration of $\mathrm{NH}_{4}{ }^{+}-\mathrm{N}$ in the sawdust layer and 0-30 $\mathrm{cm}$ depth were positively correlated with berry yields (Table S1). The concentrations of $\mathrm{NO}_{3}{ }^{-}-\mathrm{N}$ and $\mathrm{SO}_{4}{ }^{-}-\mathrm{S}$ in the soil and leachates were positively correlated with EC in the soil and leachate, but negatively correlated with $\mathrm{pH}$ in the soil and leachate (Table S1). 


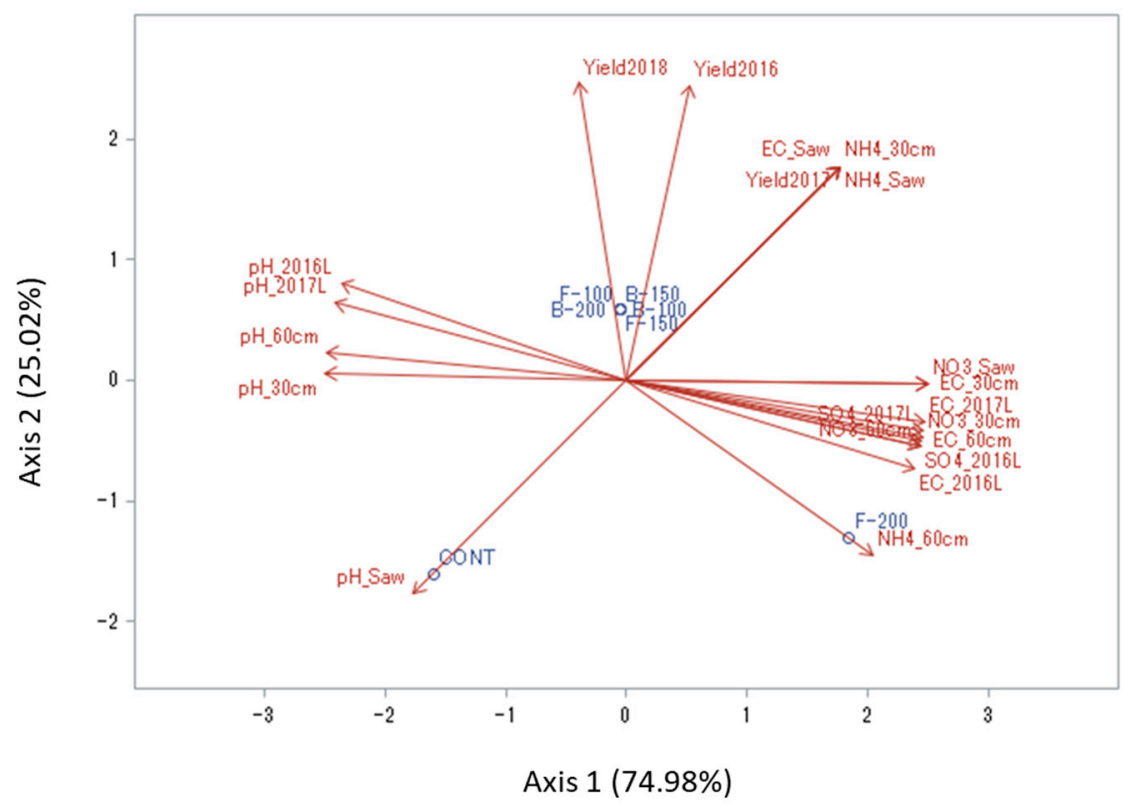

Figure 7. Correlations between berry yield and soil and leachate chemical properties as tested by principal component analysis (PCA) (Yield2016, Yield2017, Yield2018, blueberry yield in 2016, 2017 and 2018, respectively; NO3_Saw, NO3_30 cm, NO3_60 cm, soil nitrate N concentrations in the sawdust layer and 0-30 cm and 30-60 cm depth; NH4_Saw, NH4_30 cm, NH4_60 cm, soil ammonium N concentrations in the sawdust layer and $0-30 \mathrm{~cm}$ and 30-60 cm depth; pH_Saw, pH_30 cm pH_60 $\mathrm{cm}$, soil pH in the sawdust layer and 0-30 cm and 30-60 cm depth; EC_Saw, EC_30 cm, EC_60 cm, electrical conductivity in the sawdust layer and 0-30 cm and 30-60 cm depth; EC_2016L, EC_2017 L, electrical conductivity in the leachate collected in the 2016-2017 and 2017-2018 periods; SO4_2016 L, SO4_2017 L, sulfate concentrations in the leachate collected in the 2016-2017 and 2017-2018 periods; pH_2016 L, pH_2017 L, acidity in the leachate collected in the 2016-2017 and 2017-2018 periods).

\section{Discussion}

\subsection{Nutrient Concentrations in Leachates}

High rates of $\mathrm{N}$ fertilizer coupled with irrigation are generally associated with high nutrients leaching losses in horticultural crops [21]. Studies showed that $\mathrm{N}$ fertilizer applications higher than optimal rates can lead to linear or even exponential increases in the concentrations of $\mathrm{NO}_{3}{ }^{-}-\mathrm{N}$ in leachate $[20,21]$. Our results are consistent with the literature, as the concentrations of $\mathrm{NO}_{3}{ }^{-}-\mathrm{N}$, $\mathrm{NH}_{4}{ }^{+}-\mathrm{N}$ and $\mathrm{SO}_{4}{ }^{-}-\mathrm{S}$ in the leachates increased with increasing $\mathrm{N}$ fertilizer rates during the 2016/17 and 2017/18 production years (Figure 2a-c). High concentrations of nutrients in the leachate were particularly pronounced during the period of 9 May to 19 September. This period coincided with low precipitation and high temperatures (Figure 1), and therefore irrigation was applied to offset the evapotranspiration. Irrigation is widely used in highbush blueberry production because plants are shallow rooted $[19,22]$. However, irrigation triggered the downward transport of nutrients present in the rhizosphere, causing fertilizer losses and threatening the quality of groundwater. In this study, high concentrations of nutrients in the leachate were obtained under FERT compared with BROAD management although both systems were irrigated in the same way. Under FERT management, dissolved fertilizers are distributed along with irrigation water. Fertigation makes it easier for dissolved fertilizers to move downward with irrigation water through the layer of sawdust mulch covering the raised bed and into the rhizosphere and the deeper soil layer [13]. In contrast, under BROAD management, fertilizer granules are applied on the surface of the sawdust mulch. Sawdust mulch is relatively permeable to water flow [19] and much of the water available for plants originated from irrigation due to limited precipitation in the summer. Only a portion of fertilizer granules 
was dissolved and transported downward through the layer of sawdust mulch into the rhizosphere. In fact, it is known that high concentrations of $\mathrm{NH}_{4}{ }^{+}-\mathrm{N}$ remain in the sawdust layer at the end of the growing season [13]. The persistence of $\mathrm{NH}_{4}{ }^{+}-\mathrm{N}$ in the sawdust layer is thus the result of residual fertilizer granules and a low nitrification rate. Interestingly, during the period of November to April, the concentrations of nutrients in the leachates under FERT management decreased, while BROAD management experienced a mini wave of high concentrations of nutrients in the leachates, particularly $\mathrm{NO}_{3}{ }^{-}-\mathrm{N}$ and $\mathrm{SO}_{4}{ }^{-}-\mathrm{S}$ (Figures 1 and $2 \mathrm{a}, \mathrm{b}, \mathrm{e}, \mathrm{f}$ ). The residual fertilizer granules retained in the sawdust mulch are dissolved by the heavy precipitation occurring in the fall and winter, thus facilitating the downward transport of nutrients through the layer of sawdust down to deeper layers. This second wave was associated with BROAD-150 and BROAD-200, with concentrations of $\mathrm{NO}_{3}{ }^{-}-\mathrm{N}$ and $\mathrm{SO}_{4}{ }^{-}-\mathrm{S}$ in the leachates catching up to those of FERT-150 and FERT-200, particularly in the winter of the 2017/18 period (Figure 2a,b,e,f). During the period of October to February, $868 \mathrm{~mm}$ of precipitation were obtained in 2016/17 compared with $1104 \mathrm{~mm}$ in 2017/18 (Figure 1a,b). This indicates that the extra amount of precipitation obtained during the latter year contributed to higher concentrations of nutrients in the leachates compared with the year before. Several studies showed that $\mathrm{NO}_{3}{ }^{-}-\mathrm{N}$ concentrations in the leachates are higher following heavy rainfall and are therefore more closely tied to precipitation patterns [31,32].

In summary, nutrients leaching under FERT management increased with fertilizer rates and irrigation water during the dry period of the growing season and decreased in the off-season. In contrast, BROAD management experienced two periods with high concentrations of nutrients in the leachate: the first in the summer, when the plots were irrigated regularly, and the second over the winter, when the region experienced a large amount of precipitation (Figure $2 \mathrm{a}, \mathrm{b}, \mathrm{e}, \mathrm{f}$ ). Our results are important as they provide evidence of varying patterns in nutrients leaching in blueberry production systems under FERT and BROAD management. Nutrient leaching under FERT management is high and peaked during the summer owing to irrigation and decreased in the fall and winter despite heavy precipitation. Nutrient leaching under BROAD management is on average lower than FERT management, but occurred in summer owing to irrigation and in fall and winter owing to heavy precipitation. In contrast to our findings, Kowalenko [33] found that in the lower mainland of BC, there is a low risk of $\mathrm{NO}_{3}{ }^{-}-\mathrm{N}$ leaching during the spring and summer, but a high risk during fall and winter months due to the substantial rainfall the area receives at this time. Our study presents temporal patterns that need to be accounted for to track nutrient leaching in blueberry production systems in BC.

Considering Canadian regulations on $\mathrm{NO}_{3}{ }^{-}-\mathrm{N}$ concentrations in drinking water, the concentrations of $\mathrm{NO}_{3}{ }^{-}-\mathrm{N}$ in the leachates were more than 10 times the critical limit of $10 \mathrm{mg} \mathrm{L}^{-1}$ [7] for FERT-150 and FERT-200 and between 5 and 10 times for FERT-100 (Figure 2a). During the same period, the concentration of $\mathrm{NO}_{3}{ }^{-}-\mathrm{N}$ in the leachates was generally slightly above the critical limit for BROAD-100, twice the critical limit for BROAD-150 and up to four times for BROAD-200. These figures are also above standard concentrations of $\mathrm{NO}_{3}{ }^{-}-\mathrm{N}$ in groundwater from other countries and institutions, including the World Health Organization, $50 \mathrm{mg} \mathrm{L}^{-1}$ [34], the European Union, $50 \mathrm{mg} \mathrm{L}^{-1}$ [35] and US, $45 \mathrm{mg} \mathrm{L}^{-1}$ [8]. There are concerns spanning nearly 50 years on the contamination of the transboundary Abbotsford-Sumas Aquifer, which is a major drinking source for both Canadians and Americans [36]. The survey showed that between 2003 and 2013, $\mathrm{NO}_{3}{ }^{-}-\mathrm{N}$ concentrations in the Abbotsford-Sumas Aquifer increased from $10.7 \mathrm{mg} \mathrm{L}^{-1}$ to $73 \mathrm{mg} \mathrm{L}^{-1}$ [36]. Sustainable $\mathrm{N}$ fertilization and irrigation are therefore needed to reduce the concentrations of $\mathrm{NO}_{3}{ }^{-}-\mathrm{N}$ in the leachates in blueberry production systems in southern BC.

The concentrations of $\mathrm{NH}_{4}{ }^{+}-\mathrm{N}$ in the leachates are generally low because the positively charged nutrient is fixed by soil colloids [9]. However, there is a growing concern about ammonia contamination in freshwater since concentrations of total ammonia greater than $1.0 \mathrm{mg} \mathrm{L}^{-1}$ can be toxic to aquatic and semiaquatic plant species [10]. Our study showed high concentrations of $\mathrm{NH}_{4}{ }^{+}-\mathrm{N}$ in the leachates with FERT-200 during the summer period or 9 May to 19 September (Figure 2c,d). Concentrations of $\mathrm{NH}_{4}{ }^{+}-\mathrm{N}$ in the leachates as high as $4 \mathrm{mg} \mathrm{L}^{-1}$ with FERT-100 and $8 \mathrm{mg} \mathrm{L}^{-1}$ with FERT-150 were also 
measured, although during a limited period in the summer (20 June to 31 July). High concentrations of $\mathrm{NH}_{4}{ }^{+}-\mathrm{N}$ with FERT management indicate that some portion of $\mathrm{NH}_{4}{ }^{+}-\mathrm{N}$ dissolved in the FERT water was not taken up by plants or fixed by soil colloids. This can be explained by $\mathrm{NH}_{4}{ }^{+\prime}$ s ability to quickly move through the sawdust layer under FERT when irrigation is applied [22]. BROAD-based applications release $\mathrm{NH}_{4}{ }^{+}$from fertilizer granules that move more slowly through the sawdust mulch, in which $\mathrm{NH}_{4}{ }^{+}$is more susceptible to immobilization and less likely to be leached [22].

Guidelines for Canadian drinking water quality suggest that $\mathrm{SO}_{4}{ }^{2-}-\mathrm{S}$ concentrations below $500 \mathrm{mg} \mathrm{L}^{-1}$ are safe for consumption [7]. This critical limit was not reached in our study, where maximum concentrations of $\mathrm{SO}_{4}{ }^{2-}-\mathrm{S}$ in the leachates were between 250 and $350 \mathrm{mg} \mathrm{L}^{-1}$ in both years (Figure 2e,f). On the other hand, increases in $\mathrm{SO}_{4}{ }^{2-}-\mathrm{S}$ concentrations as small as $2 \mathrm{mmol} \mathrm{L}^{-1},\left(192.12 \mathrm{mg} \mathrm{L}^{-1}\right)$ have been found to negatively impact freshwater ecosystems [10]. Sulfate can enter freshwater systems by leaching into the surface or groundwater and has the potential to mobilize phosphorus, resulting in increased phosphate concentrations, which lead to eutrophication [37]. In addition, high levels of $\mathrm{SO}_{4}{ }^{2-}-\mathrm{S}$ pollution in freshwater systems can cause increases in the anaerobic decomposition of organic matter or result in sulfide toxicity when reduced [37]. Adjusting $\mathrm{N}$ fertilizer applications to optimal rates and the use of different sources of fertilizer $\mathrm{N}$ such as urea in blueberry production systems will further decrease the concentrations of $\mathrm{SO}_{4}{ }^{2-}-\mathrm{S}$ in leachates and subsequently in groundwater and freshwater systems.

\subsection{Yield}

The present study highlights decreased berry yield with $\mathrm{N}$ applications above recommended rates under BROAD management. This pattern is evidenced during the 10th and 11th year of production (Figure 6b,c). The decreased berry yield under fertigation with $\mathrm{N}$ applications above recommended rates was also observed in previous production periods [13] and was therefore carried through the 9th and 11th production years. Reasons for berry yield decrease with $\mathrm{N}$ applications above recommended rates include high EC and acidity [13]. These changes in chemical soil properties occurred in this long-term blueberry experiment because of the use of ammonium sulphate as a source of $\mathrm{N}$. The use of the large amount of $\mathrm{N}$ fertilizers above recommended rates has the potential to limit berry production and the lifespan of blueberry plantings regardless of the method of $\mathrm{N}$ applications. Reduced berry yield obtained in the 10th production year is due to the heavy pruning performed during the fall of 2016. This practice is commonly used by blueberry farmers to rejuvenate the shrubs and prolong their life span [26]. The significant trends of berry yield decrease above recommended rates that was obtained under FERT-based treatments in previous years [13] may have been altered by the heavy pruning of fall 2016.

\subsection{Relationship between Yield and the Nutrient Concentration in Leachate and Soil}

The results of PCA showed that berry yields were positively correlated with concentrations of $\mathrm{NH}_{4}{ }^{+}-\mathrm{N}$ in the sawdust layer and 0-30 cm depth (Figure 7). It is well known that blueberry plants prefer $\mathrm{NH}_{4}{ }^{+}-\mathrm{N}$ over $\mathrm{NO}_{3}{ }^{-}-\mathrm{N}$ [17] and therefore high concentrations of $\mathrm{NH}_{4}{ }^{+}-\mathrm{N}$ in the sawdust layer and $0-30 \mathrm{~cm}$ depth are favorable for blueberry $\mathrm{N}$ uptake, growth and productivity. Berry yields were also negatively correlated with the $\mathrm{pH}$ of the sawdust mulch, particularly under CONT, where persistent high $\mathrm{pH}$ values are not suitable to blueberry growth. This suggests the need for elemental sulfur in these plots to decrease the $\mathrm{pH}$ between 4.2 and 5.5, which is recommended for blueberry plantings [17]. A negative correlation was obtained between berry yields and the concentrations of $\mathrm{NH}_{4}{ }^{+}-\mathrm{N}$ in the 30-60 cm soil depth, particularly under FERT-200, probably due to the extensive leaching of this $\mathrm{N}$ form which induced low concentrations, as well as with sawdust $\mathrm{pH}$. Negative correlations were also observed between yield, soil and leachate $\mathrm{pH}$. On the other hand, $\mathrm{pH}$ was negatively related to soil EC, $\mathrm{NO}_{3}{ }^{-}-\mathrm{N}$ and $\mathrm{SO}_{4}{ }^{2-}-\mathrm{S}$. These correlations highlight how closely acidity is related to the nitrification process. In addition, the dissolution of ammonium sulfate fertilizer releases $\mathrm{SO}_{4}{ }^{2-}$ which accumulates in the soil and leachate, causing increased EC values [38,39]. In our study, EC values above critical 
limits were only obtained under FERT-200. These observations are in line with previous studies including those published from this long-term site [13,18]. Bryla and Machado [40] observed that large amounts of ammonium sulfate fertilizers result in increased soil EC and salt stress in blueberry plants, and consequently yield reduction.

\section{Conclusions}

Nutrients $\left(\mathrm{NO}_{3}{ }^{-}-\mathrm{N}, \mathrm{NH}_{4}{ }^{+}-\mathrm{N}\right.$ and $\left.\mathrm{SO}_{4}{ }^{-}-\mathrm{S}\right)$ leaching in this long-term blueberry field was increased by $\mathrm{N}$ applications during the 2016/17 and 2017/18 production years. High concentrations of nutrients in the leachate were pronounced during the summer due to irrigation. FERT and BROAD management increased the concentrations of $\mathrm{NO}_{3}{ }^{-}-\mathrm{N}$ in the leachates between 2 and 10 times the standard recommendations for groundwater quality. BROAD management highlighted two waves of high $\mathrm{NO}_{3}{ }^{-}-\mathrm{N}$ in the leachates, the first in the summer due to irrigation water and the second in the fall and winter associated with heavy precipitations. Our results also indicate a yield decrease with $\mathrm{N}$ applications above recommended rates under BROAD management as previously observed under FERT management. Accumulation of mineral $\mathrm{N}$ in the soil and its ripple effect on $\mathrm{pH}$ and EC negatively affect berry yield with time. It is therefore important to tailor $\mathrm{N}$ management to plant needs with broadcast or fertigation application to limit nutrients leaching and to sustain the long-term productivity of blueberry farms.

Supplementary Materials: The following are available online at http:/www.mdpi.com/2223-7747/9/11/1530/s1, Table S1: Pearson's correlation matrix among berry yields and chemical properties of soil and leachate.

Author Contributions: Conceptualization, A.J.M. and D.H.; Data curation, K.D., K.R. and K.v.B.; Formal analysis, S.Y.; Funding acquisition, A.J.M.; Investigation, A.J.M.; Methodology, D.H., S.Y. and M.D.; Resources, D.H.; Writing —original draft, A.J.M., K.D., K.R. and K.v.B.; Writing—review and editing, A.J.M. and M.D. All authors have read and agreed to the published version of the manuscript.

Funding: This work was funded by Agriculture and Agri-Food Canada through an A-Base program (Project ID: J-001401-Sustainable production and genetic enhancement of small fruit crops with improved market oriented quality attributes).

Conflicts of Interest: All authors declare no conflict of interest.

\section{References}

1. Padilla, F.M.; Gallardo, M.; Manzano-Agugliaro, F. Global trends in nitrate leaching research in the 1960-2017 period. Sci. Total Environ. 2018, 643, 400-413. [CrossRef] [PubMed]

2. Chen, Z.; Wang, L.; Wei, A.; Gao, J.; Lu, Y.; Zhou, J. Land-use change from arable lands to orchards reduced soil erosion and increased nutrient loss in a small catchment. Sci. Total Environ. 2019, 648, 1097-1104. [CrossRef] [PubMed]

3. Rezaei, F.; Zadeh, H.G.; Van Damme, P. Impacts of inorganic nitrogen fertiliser on soil fertility and groundwater quality of touba orchards (western Iran). J. Environ. Prot. Ecol. 2013, 14, 71-79.

4. Zebarth, B.J.; Kowalenko, C.G.; Harding, B. Soil inorganic nitrogen content and indices of red raspberry yield, vigor, and nitrogen status as affected by rate and source of nitrogen fertilizer. Comm. Soil Sci. Plant Anal. 2007, 38, 637-660. [CrossRef]

5. Kiani, M.; Raave, H.; Simojoki, A.; Tammeorg, O.; Tammeorg, P. Recycling lake sediment to agriculture: Effects on plant growth, nutrient availability, and leaching. Sci. Total Environ. 2020, 753, 141984. [CrossRef]

6. Hester, R.E.; Harrison, R.M.; Addiscott, T.M. Fertilizers and nitrate leaching. In Agricultural Chemicals and the Environment; Hester, R.E., Harrison, R.M., Eds.; The Royal Society of Chemistry: Cambridge, UK, 1996; pp. $1-26$.

7. Health Canada. Guidelines for Canadian Drinking Water Quality Summary Table. 2019. Available online: https://www.canada.ca/en/health-canada/services/environmental-workplace-health/ reports-publications/water-quality/guidelines-canadian-drinking-water-quality-summary-table.html (accessed on 24 October 2020). 
8. U.S. EPA. Nitrates and Nitrites. TEACH Chemical Summary. U.S. EPA, Toxicity and Exposure Assessment for Children's Health; Environmental Protection Agency: Washington, DC, USA, 2007. Available online: www.epa.gov/teach/chem_summ/Nitrates_summary.pdf (accessed on 24 October 2020).

9. Moreno, F.; Cabrera, F.; Murillo, J.M.; Fernandez, J.E.; Fernandez-Boy, E.; Cayuela, J.A. Nitrate leaching under irrigated agriculture. In Sustainability of Irrigated Agriculture; Pereira, L.S., Feddes, R.A., Gilley, J.R., Lesaffre, B., Eds.; Springer: Dordrecht, The Netherlands, 1996; pp. 407-415.

10. Lamers, L.P.M.; Tomassen, H.B.M.; Roelofs, J.G.M. Sulfate-induced eutrophication and phytotoxicity in freshwater wetlands. Environ. Sci. Technol. 1998, 32, 199-205. [CrossRef]

11. Thurston, R.V.; Russo, R.C.; Luedtke, R.J.; Smith, C.E.; Meyn, E.L.; Chakoumakos, C.; Wang, K.C.; Brown, C.J.D. Chronic toxicity of ammonia to rainbow trout. Trans. Am. Fish. Society. 1984, 113, 56-73. [CrossRef]

12. Ercoli, L.; Arduini, I.; Mariotti, M.; Lulli, L.; Masoni, A. Management of sulphur fertilizer to improve durum wheat production and minimise $S$ leaching. Eur. J. Argon. 2012, 38, 74-82.

13. Messiga, A.; Haak, D.; Dorais, M. Blueberry yield and soil properties response to long-term fertigation and broadcast nitrogen. Sci. Hortic. 2018, 230, 92-101. [CrossRef]

14. Eriksen, J.; Askegaard, M. Sulphate leaching in an organic crop rotation on sandy soil in Denmark. Agric. Ecosyst. Environ. 2000, 78, 107-114. [CrossRef]

15. Eriksen, J.; Murphy, M.D.; Schnug, E. The soil sulphur cycle. In Sulphur in Agroecosystems; Schnug, E., Ed.; Kluwer Academic Press: Dordrecht, The Netherlands, 1998; pp. 39-73.

16. Guzys, S.; Aksomaitiene, R. Migration of sulphur in limed soils differing in agricultural management. Nutr. Cycl. Agroecosyst. 2005, 71, 191-201. [CrossRef]

17. Poonnachit, U.; Darnell, R. Effect of ammonium and nitrate on ferric chelate reductase and nitrate reductase in Vaccinium species. Ann. Bot. 2004, 93, 399-405. [CrossRef] [PubMed]

18. Forge, T.; Ehret, D.; Messiga, A.; Dorais, M. Influences of nitrogen inputs on nematode populations under highbush blueberry. J. Nematol. 2020, 52, e2020-56. [CrossRef] [PubMed]

19. Holzapfel, E.A.; Hepp, R.F.; Mariño, M.A. Effect of irrigation on fruit production in blueberry. Agric. Water Manage. 2004, 67, 173-184. [CrossRef]

20. Wang, Y.; Ying, H.; Yin, Y.; Zheng, H.; Cui, Z. Estimating soil nitrate leaching of nitrogen fertilizer from global meta-analysis. Sci. Total Environ. 2019, 657, 96-102. [CrossRef]

21. Cui, M.; Zeng, L.; Qin, W.; Feng, J. Measures for reducing nitrate leaching in orchards: A review. Environ. Pollut. 2020, 263, 114553. [CrossRef]

22. Ehret, D.L.; Frey, B.; Forge, T.; Helmer, T.; Bryla, D.R.; Zebarth, B.J. Effects of nitrogen rate and application method on early production and fruit quality in highbush blueberry. Can. J. Plant. Sci. 2014, 94, 1165-1179. [CrossRef]

23. Adu-Gyamfi, R.; Agyin-Birikorang, S.; Tindjina, I.; Manu, Y.; Singh, U. Minimizing nutrient leaching from maize production systems in northern Ghana with one-time application of multi-nutrient fertilizer briquettes. Sci. Tot. Environ. 2019, 694, 133667. [CrossRef]

24. Zvomuya, F.; Rosen, C.J.; Russelle, M.P.; Gupta, S.C. Nitrate leaching and nitrogen recovery following application of polyolefin-coated urea to potato. J. Environ. Qual. 2003, 32, 480-489. [CrossRef]

25. Soil Survey Staff. Keys to Soil Taxonomy, 11th ed.; NRCS: Washington, DC, USA, 2010.

26. BCMAL. British Columbia Ministry of Agriculture and Lands, BC Berry Production Guides. 2020. Available online: https://www2.gov.bc.ca/gov/content/industry/agriservice-bc/production-guides/berries (accessed on 3 September 2020).

27. Woodard, K.R.; French, E.C.; Sweat, L.A.; Graetz, D.A.; Sollenberger, L.A.; Macoon, B.; Portier, K.M.; Rymph, S.J.; Wade, B.L.; Prine, G.M.; et al. Nitrogen removal and nitrate leaching for two perennial, sod-based forage systems receiving dairy effluent. J. Environ. Qual. 2003, 32, 996-1007. [CrossRef]

28. Maynard, D.G.; Kalra, Y.P.; Crambaugh, J.A. Nitrate and exchangeable ammonium nitrogen. In Soil Sampling and Methods of Analysis, 2nd ed.; Carter, M.R., Gregorich, E.G., Eds.; CRC Press: Boca Raton, FL, USA, 2007; pp. 607-616.

29. Tabatabai, M.A. A rapid method for determination of sulfate in water samples. Environ. Lett. 1974, 7, $237-243$. [CrossRef]

30. Statistical Analysis System. User's Guide: Statistics, Version 9, 3rd ed.; SAS Inst.: Cary, NC, USA, 2010.

31. Malekani, F.; Ryan, M.C.; Zebarth, B.J.; Loo, S.E.; Suchy, M.; Cey, E.E. A field scale approach to estimate nitrate loading to groundwater. J. Environ. Qual. 2018, 47, 795-804. [CrossRef] [PubMed] 
32. Wang, H.; Gao, J.-E.; Li, X.-H.; Zhang, S.-L.; Wang, H.-J. Nitrate accumulation and leaching in surface and ground water based on simulated rainfall experiments. PLoS ONE 2015, 10, E136274. [CrossRef] [PubMed]

33. Kowalenko, C.G. The dynamics of inorganic nitrogen in a Fraser Valley soil with and without spring or fall ammonium nitrate applications. Can. J. Soil Sci. 1987, 67, 367-382. [CrossRef]

34. World Health Organization (Ed.) Guidelines for Drinking-Water Quality, 4th ed.; World Health Organization: Geneva, Switzerland, 2011.

35. Directive, C. Concerning the protection of waters against pollution caused by nitrates from agricultural sources. Off. J. Eur. Commun. 2013, 375, 1-8.

36. Carey, B.M.; Cummings, R. Sumas-Blaine Aquifer Nitrate Contamination Summary; Department of Ecology State of Washington: Washington, DC, USA, 2013.

37. Lamers, L.P.M.; Vile, M.A.; Grootjans, A.P.; Acreman, M.C.; van Diggelen, R.; Evans, M.G.; Richardson, C.J.; Rochefort, L.; Kooijman, A.M.; Roelofs, J.G.M.; et al. Ecological restoration of rich fens in Europe and North America: From trial and error to an evidence-based approach. Biol. Rev. 2015, 90, 182-203. [CrossRef]

38. Machado, R.M.A.; Bryla, D.R.; Vargas, O. Effects of salinity induced ammonium sulfate fertilizer on root and shoot growth of highbush blueberry. Acta Hortic. 2014, 1017, 407-414. [CrossRef]

39. Bryla, D.R.; Machado, R.M.A. Comparative effects of nitrogen fertigation and granular fertilizer application on growth and availability of soil nitrogen during establishment of highbush blueberry. Front. Plant Sci. 2011, 2, 1-8. [CrossRef]

40. Bryla, D.R.; Shireman, A.D.; Machado, R. Effects of method and level of nitrogen fertilizer application on soil $\mathrm{pH}$, electrical conductivity, and availability of ammonium and nitrate in blueberry. Acta. Hort. 2010, 868, 95-101. [CrossRef]

Publisher's Note: MDPI stays neutral with regard to jurisdictional claims in published maps and institutional affiliations.

(C) 2020 by Her Majesty the Queen in Right of Canada, as represented by the Minister of Agriculture and Agri-Food Canada; licensee MDPI, Basel, Switzerland. This article is an open access article distributed under the terms and conditions of the Creative Commons Attribution (CC BY) license (http://creativecommons.org/licenses/by/4.0/). 